\title{
THE EFFECTS OF COMMUNICATION MEDIUMS ON THE EVOLUTION OF MODERN AND CONTEMPORARY WESTERN POETRY
}

\author{
by \\ Sarah Ostapchuk \\ Honours Bachelor of Arts, 2014-2018, University of Toronto \\ An MRP presented to Ryerson University \\ in partial fulfillment of the requirements of the degree of \\ Master of Professional Communication \\ in the program of \\ Professional Communication
}

Toronto, Ontario, Canada, 2020

(C) Sarah Ostapchuk, 2020 


\section{AUTHOR'S DECLARATION}

I hereby declare that I am the sole author of this MRP. This is a true copy of the MRP, including any required final revisions.

I authorize Ryerson University to lend this MRP to other institutions or individuals for the purpose of scholarly research.

I further authorize Ryerson University to reproduce this MRP by photocopying or by other

means, in total or in part, at the request of other institutions or individuals for the purpose of scholarly research.

I understand that my MRP may be made electronically available to the public. 


\begin{abstract}
This study analyses how popular communication mediums over the past century have changed the form and content of poetry. A periodical and small magazine published in 1912 are assessed and compared, as well as an anthology and several poems from Instagram published in 2014. All poems are also briefly compared to get an understanding of change over time. Medium affordances are considered, especially with respect to multimodal capacities. By assessing vocabulary density, word frequency, word distinctiveness, and visual formatting, characteristics of poetry from specific mediums arise, leading to a conclusion that mediums have an effect on the evolution of poetry.
\end{abstract}




\section{Table of Contents}

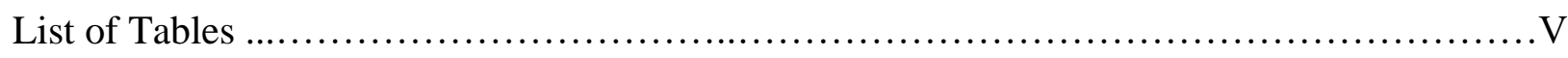

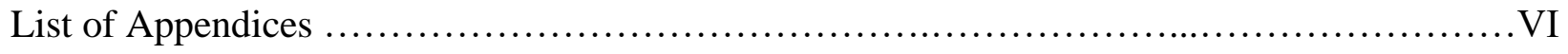

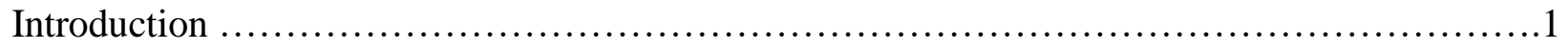

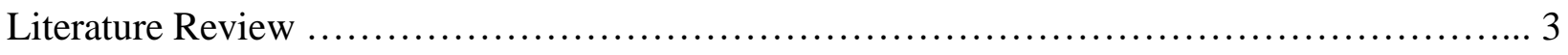

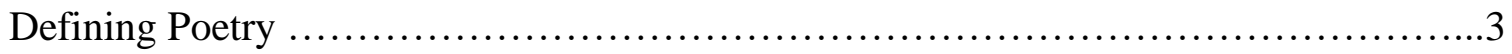

Affordances of Mediums from a Sociopolitical Context..............................8

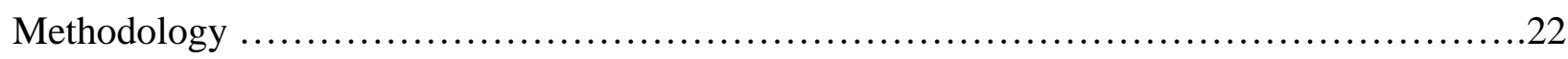

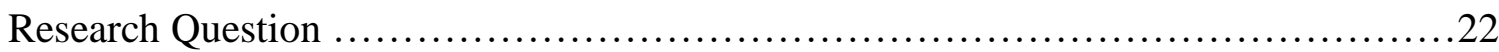

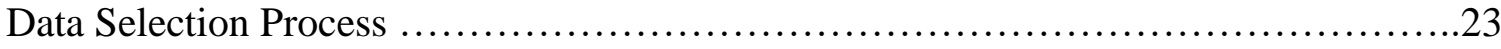

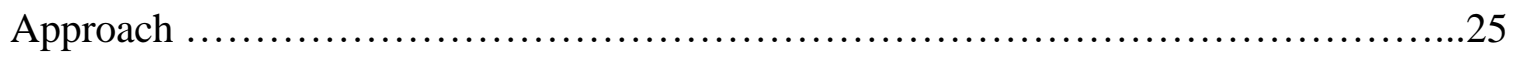

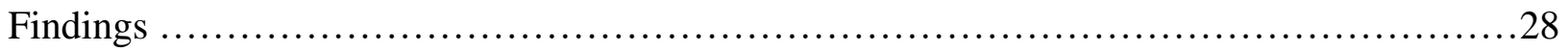

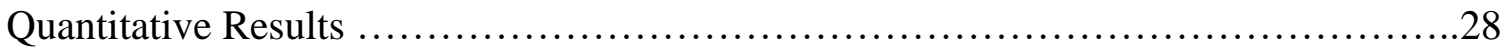

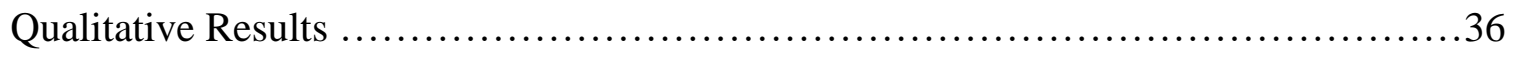

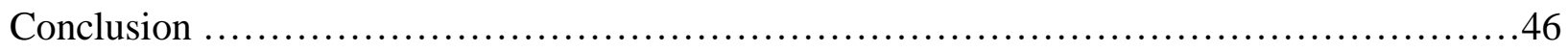

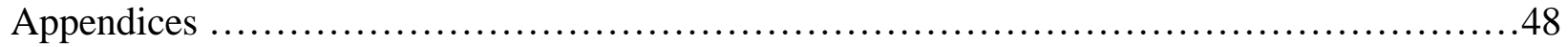

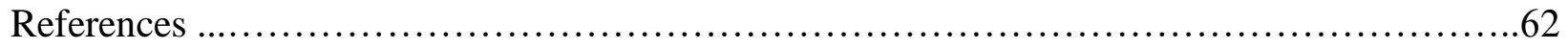




\section{List of Tables}

Table 1: Elements of Vocabulary Density of All Mediums .............................28

Table 2: Distinct Words and their Parts of Speech for All Mediums ...........................34 


\section{List of Appendices}

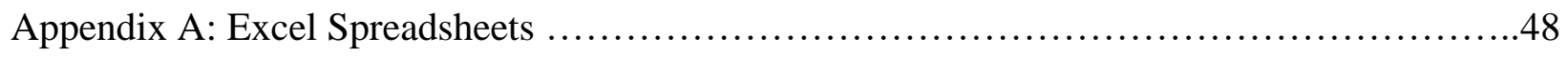

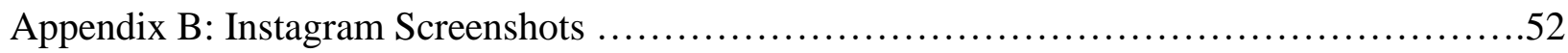

Appendix C: Qualitative Analysis Poem Screenshots ..................................57 


\section{Introduction}

The linguistic study of poetry is not new; researchers have created many corpuses of poetic text from the twentieth century and prior. However, there is little research that includes contemporary poetry, especially non-print works that are digitally based, such as Instagram poetry. Many scholars and critics do not consider the work published on Instagram to be poetry, and thus reject it from the canon (Naji, 2018) This study seeks to include Instagram poetry into the canon by assessing the definition of poetry, which has historically eluded scholars, critics, and poets. Though it does not fit the highly stylized, exclusive characteristics that some attribute to the genre, it has enjoyed global success and been recognized as poetry by the public, a feat which cannot be ignored (Pâcquet, 2019). Instagram also employs multimodality, a way of communicating that uses multiple modes of communication, for instance, text, images, sound, video, and any combination of these (Kress, 1998). Instagram has also been able to revive poetry and make it relevant to a new generation through accessibility of language and digital reach (Pâquet, 2019). For these reasons, Instagram poems are included in this study of communication mediums and their affordances in relation to poetry dissemination.

Also uncommon in linguistic studies of poetry is a communications approach. A medium refers to a communication tool for sharing information with the public, which can take on many forms, such as a printed periodical or a social media application. This study is focused exclusively on how communication mediums that publish poetry have changed the evolution of poetry through dictating form and content. Harper's, Poetry, The Best American Poetry 2014, and Instagram are the communication mediums that have been selected for comparison. Harper's is a periodical, popular not just for poetry but journalism and prose and used to 
circulate poetry in the nineteenth and twentieth centuries (Brinkman, 2009). Poetry, which is a small magazine, focused exclusively on poetry and was created in the early twentieth century (Brinkman, 2009). The Best American Poetry 2014 is an example of an anthology, a collection of print poetry that is still relevant as a medium today. Lastly, Instagram poetry has been selected as a digital contemporary medium. Each medium is discussed and considered within the sociopolitical context of each time period, as sociopolitical context can have a major effect on poetry movements and change in poetry over time (Kress, 1998).

This study hopes to offer a new perspective on linguistic analysis, poetry analysis, and the poetic canon through the lens of communications studies. It also hopes to contribute to new methods of analysing digital and multimodal poetry. 


\section{Literature Review}

This literature review discusses historical and popular ways of defining poetry, ultimately arriving at the conclusion that there is no consensus, and what is considered poetry can be as subjective as the artform itself. This information is set up as a prerequisite for understanding how poetry has shifted through sociopolitical context and technological change. These changes are a frame for discussing the changes in communication mediums, which themselves inflict change upon poetry and is the larger question this study is asking. After considering what poetry can be defined as and how historical and social context and technologies affect its evolution, a discussion can be had about how mediums dictate what poetry will look like.

\section{Defining Poetry}

In order to better understand how different communication tools change poetry, there needs to be a discussion of the definition of poetry from a Western perspective. Despite many great thinkers grappling with finding a definition, there is no consensus. There are, however, schools of thought that different groups of people ascribe to. This study takes all of the following methods of defining poetry into consideration in order to accept a more encompassing definition that includes more kinds of poetry. This is especially important when considering how different time periods, cultures, technological advancements, and societal values changed what people considered poetry to be. The following thinkers are representative of thousands of years of thought on poetry, which influence our current stance on poetry today.

The dilemma of defining poetry can be traced at least as far back as Plato, who is one of the first thinkers to touch on the notion of poetry being defined by its exclusivity (c. 375 BC). The Republic contains a series of arguments concerning the state and government as well as art 
and imitation in the form of Socratic dialogue (Plato, c. 375 BC). To explain his reasoning, Plato uses an analogy of a carpenter constructing a chair or a table (Plato, c. 375 BC). Plato explains that the carpenter making the furniture is not truly creating anything, but rather his creation is actually an "imitation" (Plato, c. 375 BC, 595a) of an "idea" (Plato, c. 375 BC, 596b). Similarly, art in all its forms is created by man, the subject of which can only be creation (Plato, c. 375 BC). Therefore, all art is a mere imitation of God's original work (Plato, c. 375). For Plato, imitation is repulsive and should only be admitted into society with the utmost caution (Plato, c. 375 BC). He deems poets and playwrights like Homer three times removed from original creation, and thus the worst kind of imitators, as they are the farthest from the "truth" (Plato, c. $375 \mathrm{BC}, 596 \mathrm{e})$. Though imitation is base, Plato allows that some is necessary for society and serves a purpose. However, too much imitation will result in lesser valued art that is further and further away from the original (Plato, c. 375 BC). Herein lies a very common theme of using exclusivity as a defining characteristic of poetry.

Over 1500 years later, this concept appears in the work of Walter Benjamin, a German philosopher who contributed to many schools of thought in the twentieth century, most notably in this case as a literary critic and essayist (Osborne \& Charles, 2015). Though his theories have been broadly applied in ways that are not always true to his original intent, they have influenced many great thinkers, such as Jacques Derrida and Jürgen Habermas (Osborne \& Charles, 2015). His piece entitled "The Work of Art in the Age of Mechanical Reproduction" directly influenced Stein in his much later writing of "The Work of Art in the Age of Digital Reproduction", where he uses Benjamin's ideas to frame a discussion of poetry in the digital age (Stein, 2010). Benjamin (1982) posits that imitation of artwork has been practiced for centuries, but what is new and threatening is the rate and magnitude of replication afforded by mechanization. Though 
imitation is not nearly as exact as replication, this distinction he makes between an acceptable and unacceptable amount is similar to Plato (Benjamin, 1982). Benjamin also more pointedly suggests through his mountain metaphor that art should be exclusive to keep it intact as art (Benjamin, 1982). The best art to be experienced is at the top of the mountain, making it the most difficult to get at and allowing the fewest amount of people to view it at one time due to the cone/pyramid-like shape (Benjamin, 1982). This notion of exclusivity shared by Plato and Benjamin is an elitist understanding of art; if only a finite number of imitations or replications are permitted, this inevitably will exclude a large group of people from experiencing true art.

Exclusivity is grounded in tradition, much like another method of defining poetry: through a rigid set of stylistic rules. E. Warwick Slinn argues that poetry is "a highly organized form of language" and is "too self-enclosed in its formalist processes to relate directly to social practices" (Slinn, 1999, p. 57). There is also a specificity in poetry which makes it unrelatable to other artforms (Slinn, 1999). Based on his definition, Slinn is only allowing the genre to include work that is rigid in style and outdated in content, most likely traditional poetry. Harriet Munroe, American editor, poet, and contributor to the Poetry magazine also relates to this rigidity in style (Brinkman, 2009). The magazine was created for poets starving for room in crowded, competitive periodicals (Brinkman, 2009). It was also meant to put less of a restraint on poets and allow for a freer acceptance of poetry (Brinkman, 2009). Ironically, the full title of the new magazine was called, Poetry: A Magazine of Verse, which not only associates poetry with verse, a highly stylized way of writing, but equates the two as synonymous, further reinforcing the idea that poetry must adhere to certain formatting (Brinkman, 2009). Munroe, herself an editor, wrote about Poetry's wide acceptance of diversified verse while also calling those who wrote fiction 
"paragraphers", again using a form of writing as a way of distinguishing genre (Brinkman, 2009, p. 32).

Still in a similar vein is the notion of poetry as canonical works. Edgar Lee Masters, attempting to define poetry in an issue of Poetry, researched famous poets and their thoughts on the artform, such as Coleridge, Shelley, and Plato (Masters, 1915). He was met with contesting definitions and decided that it was impossible to succinctly define poetry beyond what is already universally accepted as standard, or traditional poetry, such as William Shakespeare or biblical verse (Masters, 1915).

Despite the existence of several defining methods based on stylistic restrictions, perhaps one of the most common ways the genre has been defined is precisely by its lack of definition; its mystery. Walter Benjamin, Harriet Munroe, and Edgar Lee Masters are all advocates of this feature of poetry, particularly Benjamin. He uses the word "aura", which he describes as "the unique phenomenon of a distance”, to encompass art and its effects (Benjamin, 1982, p. 219). He likens it to the shadows of tree branches and looming mountains. Though this term is vague, the inability to "touch" art literally due to its distance and figuratively due to ambiguous terminology is what defines art. Benjamin's term "aura" is spiritual, magical, and mysterious, which are common adjectives used by other thinkers (Benjamin, 1982, p. 219). Masters, after attempting a definition in his commentary in Poetry, comes to the conclusion that the best way to understand poetry is not by its form, but by its "substance", an ambiguous term that he does not try to define further (Masters, 1915, p. 307). In a similar tone, he also mentions that “...poetry is the orientation of the soul to the conditions of life..." (Masters, 1915, p. 307). Munroe also shows a belief in an abstract sense of what makes poetry different from other genres, which she calls "the poetic effect" and "the magic touch" (Brinkman, 2009, p. 31). 
In contemporary times, thinkers have been revisiting the idea of allowing popularity to dictate what is considered poetry. Though historically, artists, critics, and theorists have viewed the academic and public spheres as separate, the immense popularity and success of Instagram poetry, an accessible genre both intellectually and physically, has challenged this notion (Pâquet, 2019). Pâquet states, "to date, academic scholarship has largely overlooked Instagram poetry, usually considering it a lowbrow form that demonstrates little literary merit” (Pâquet, 2019, p. 296). She credits this to a persisting binary between academia and popular culture (Pâquet, 2019). Pâquet believes this binary omits the consideration of the importance of public reception and the legitimation that it may afford (Pâquet, 2019). Allowing the public to decide what should count as poetry would widen the scope of poetry and allow for twenty-first century Instagram poetry to be admitted into the canon.

Literary merit, for many critics, is what is missing from newer forms of poetry (Pâquet, 2019). This opinion may be shared by many intellectuals, but the concept of literary merit is just as hard to pinpoint as the genre of poetry, and it is ultimately subjective. Arguments against allowing the public to decide what is good enough to be called poetry and what is not include the risk of the work being "cheapened" by "pandering" to the public, something popular culture in the form of music and film has been found guilty of (Stein, 2010). When an artist is concerned with attracting attention, the art will no longer be about what the artist wants to portray, but what they believe will sell. The validity of this is contested by the equally dangerous risk of guarding the gates to the poetic canon, which historically has restricted the admittance of ethnic minorities, women, and other marginalized groups (Newcomb, 2004). For this reason, when considering the merit of poetry, sociopolitical context and how it has allowed for the admittance of marginalized groups is important to keep in mind. 


\section{Affordances of Mediums from a Sociopolitical Context}

Poetic convention is a reflection of the social values of the time period, which is historically true for poetry. As noted by Slinn (1999), poems gain their meaning from the cultural, social, and historical context from which they derive. He states that poetry "is also itself a cultural event which participates in cultural reality, reconstituting or reshaping that reality in the very act of reiterating its norms" (Slinn, 1999, p. 66). Therefore, comparing two poems that are written a century apart will result in stark differences that are not solely caused by the communication medium, but by the contrasting social and political landscapes of the time periods. For this reason, it is important to understand how society has changed between the nineteenth, twentieth, and twenty-first centuries (which are the time periods that all poetry samples will be taken from) in order to isolate the affect the communication medium is having in the poetry. For each medium discussed, the sociopolitical context of the time period in which it flourished will also be discussed.

Communication mediums can dictate how information is received and processed by readers due to the layout and modes of communication employed. Even within one form of media, such as print, the addition of images, colour, and larger text can drastically change the way the information is being received (Kress, 1998). Newspapers in the 1960s were characterized by heavy blocks of black and white text, while in the 1990s, images took up most of the space on the page (Kress, 1998). Similarly, 1960s television news programs featured a "Newsreader", which later became the "News anchor", stressing the visual component rather than the textual (Kress, 1998, p. 58). The same is true for poetry; different mediums will change the readability of poems as well as the evolution of poetry form and content convention. For example, some mediums might allow for longer poems, while others might only allow a fraction 
of a page. This will be further discussed in regards to four mediums: nineteenth to twentieth century periodicals, twentieth century small magazines, print collections in the form of anthologies, and Instagram.

\section{Nineteenth and Twentieth Centuries: Periodicals and Small Magazines}

At the turn of the nineteenth century, the American poetic canon was coming together, and it was extremely homogenous (Newcomb, 2004). It consisted of writers like Henry Wadsworth Longfellow, John Greenleaf Whittier, and Oliver Wendell Holmes, who were white males, as their names indicate (Newcomb, 2004). Beyond their ethnicity and gender, their writing focused on the same ideas, which was one narrative: that of a yearning for a nostalgic, pastoral past, which they employed against the unfeeling rush of modernization (Newcomb, 2004). This translated into a moralism that connected virtue and purity to the simpler, natural life that was being threatened by the dirty cities and manufacturing of mechanization, which brought along with it amoral ideals. This concept appealed to Americans who were "earnest, highminded," and "distrustful of difference and nonconformity" (Newcomb, 2004, p. 7). Newcomb's words hint at an audience that was not only skeptical and cautious of the new mechanized world, but of contrasting cultures, religion, and non-Western experiences which came with these new changes. However, recent scholarship has acknowledged that during this time, important poetry that looked very different from the canon but is now considered of equal merit existed (Newcomb, 2004). This work did not receive its due because it did not conform to the American canon at the time.

The period between 1890 and 1910 has been pinpointed by scholars as a transformative time for poetry (Newcomb, 2004). There began a paradoxical distrust of tired, old forms and a refusal to accept any new forms (Newcomb, 2004). Out of this period emerged a societal 
acceptance of a wider variety of works with less restrictive perimeters. This poetry, after 1912, was called "New Poetry" (Newcomb, 2004, p. xxi). Newcomb's definition of modern poetry is the following:

“.... an impulse to resist or challenge traditions; a tendency to measure literary value through the creation of distinctive forms and unique authorial voices; an affinity for irony, historical awareness, and self-reflexivity; an ambivalent attraction to other cultural genres and disciplines; an interest in articulating oppositional political positions; and above all, deep engagement, however anxious or oppositional, with the conditions of modern life.” (Newcomb, 2004, p. xxi)

Newcomb's definition highly contrasts the poetry that immediately preceded it. Instead of consistency, uniformity, and universality, modern poetry sought for diversity, self-awareness, and criticism or, at the very least, skepticism, of norms (Newcomb, 2004). This new direction carved the path that would allow non-white poets and non-traditional poets to be accepted into the canon and appreciated by scholars and critics.

With this in the backdrop, poetry was being disseminated through multiple avenues, two of which were periodicals and small magazines. Though periodicals have a much longer history than small magazines, these communication mediums eventually operated at the same time during 1912 and after, and thus within the same historical, social, and cultural context. Despite this, they had very different affordances and created very different spaces for poetry.

Periodicals in the nineteenth century contained journalism, images, fiction, and poems (Brinkman, 2009). They were widely circulated, but the poetry was never the content that brought in revenue (Brinkman, 2009). Popular periodicals during the late nineteenth century 
included The Atlantic, Harpers, and The Century (Brinkman, 2009). Between the 1820s and 1830s, technological advancements in printing led to cheaper mass production of periodicals, up to a million copies, making the periodicals inexpensive to buy and widening their circulation (Newcomb, 2004). Because of this wide circulation, the public was being exposed to the poetry of the elite, which they found irrelevant to their lives and therefore generally disliked (Newcomb, 2004). Due to this growing dislike and lack of revenue, poems began receiving less and less space in each periodical (Newcomb, 2004). Considering periodicals were written for and targeted toward the widest audience possible, poets began to be creatively constrained and limited to short verses that were straightforward and had a quality of "stylelessness" (Newcomb, 2004, p. 62). Ezra Pound expressed his frustration with the popular periodicals of the day, accusing them of doing damage to the public mind (Brinkman, 2009).

Placing a poem on the same page as cartoons, jokes, or political pieces, which is what periodicals did, changed the meaning and understanding of the poem due to this juxtaposition (Brinkman, 2009). Though pictures were not usually involved, periodicals employed many genres, most of which were side by side or within a single page, which is a multimodal way of communicating (Kress, 1998). Kress (1998) also argues that text alone can be multimodal depending on what is being depicted. This type of communication, which will be discussed later in greater detail, can change the way information is received and, like Brinkman (2009) mentions, can change the meaning of the poetic work (Kress, 1998). Some periodicals would print poems within columns, like the rest of the content, also changing the form of the poems and thus their reception (Brinkman, 2009).

As the quality of poetry began to plummet, the frustration of poets toward periodicals began to rise (Brinkman, 2009). A separation occurred between popular verse and real poetry in 
the form of poets seeking a new medium in which to display their work (Brinkman, 2009). The little magazine name refers to the scope and reach of the magazine rather than the size (Brinkman, 2009). The magazine Poetry was founded in 1912 not as a competitor of popular periodicals, but as an entirely different publication targeted toward the poetry lovers of America (Brinkman, 2009). This magazine was also meant to push for poetry that did not follow the traditional norms, but was experimental; a characteristic of the emerging modernist movement (Brinkman, 2009). Poetry was instrumental in disseminating modern poetry and is cited as the medium that helped realize the imagism movement in poetry (Brinkman, 2009). In fact, a popular belief persists in scholarship that Ezra Pound's publication in Poetry's first October 1912 issue was what started the era of modern poetry in America (Newcomb, 2004).

Poetry magazine distinguished itself from other periodicals not only by its contents, but its display of contents (Brinkman, 2009). Rather than a simple periodical that is consumed and then thrown away within an afternoon, Poetry was made with an aesthetic appeal so that it might sit on a shelf as a collectible (Brinkman, 2009). Instead of cluttered pages, each page displayed one poem (Brinkman, 2009). This space allowed for longer forms of poems as well as the freedom of poets to play with spacing and line breaks, such as with Ezra Pound's "In a Station of the Metro", the spacing of which remained intact in Poetry, whereas other publications that featured the poem did not keep Pound's original, odd spacing (Brinkman, 2009). Poetry as a communication medium was a forerunner for modernist poets by allowing them more freedom in their style and length of writing.

Poetry was not the only small magazine that was reshaping poetry during this time. In 1915, a newer outlet that was even more experimental and accepting of non-traditional verse published its first issue, called Others: A Magazine of the New Verse (Churchill, 1998). It was 
vitally important to the Modernist movement in a way that was less mainstream than Poetry due to Others" "radical" associations (Churchill, 1998, p. 48). Editor Kreymborg accepted more poems written by female writers than most publications and much more sexually explicit content, all while attempting to operate as neutrally in the background as possible (Churchill, 1998). He even omitted an editor's note or introduction in the first issue and let the poetry speak for itself (Churchill, 1998). Churchill (1998) called it "an unregulated forum that promised liberty and equality to all" (p. 49). Though Others pushed further the acceptable boundaries that Modernism was also testing in a way that made Poetry look run-of-the-mill, both small magazines afforded space and acceptance, and thus flexibility in form and content for poets. They were also detached from the priority of selling as many copies as possible and focussed on a small, exclusive group of readers.

Though both communication mediums were print-based and mainly textual, periodicals and small magazines offered immensely different spaces for poetry. Due to the dominance of other genres of writing in the periodical, poetry had to fit within the margins of other works both in size, visually, and in content (Brinkman, 2009). Poems were lighter and simpler (Newcomb, 2004). Small magazines, such as Poetry and Others, were divorced from the goal of high revenue and instead focused on the content of the publication, pushing for work that looked different from any pre-existing poetry (Churchill, 1998). Single poems enjoyed whole pages or multiple pages and were not nearly as restricted in subject matter (Brinkman, 2009). They were also physically created to be keepsakes, as they contained work that was meant to be displayed and re-read, unlike periodicals (Brinkman, 2009).

\section{The Twenty-first Century: Anthologies and Instagram}


The twenty-first century looked a lot different from the last turn of the century, though trends progressed in a similar direction. Society had become and continues to become informal as genre barriers break down (Kress, 1998). This move into the informal has been caused by social, political, and economic factors (Kress, 1998). Along with informality, a dramatic shift from the dominance of text and writing to visual representation occurred (Kress, 1998). The education system did not keep up with this change and lacked the ability to teach visually (Kress, 1998). This stress on writing has also negatively affected cultural representation and cognitive abilities, as many cultures still put stress on oral or visual tradition (Kress, 1998). Thus, a shift to informality and non-textual formats of representation allowed marginalized groups into canons and academic circles.

When social actions persist and are consistent, new genres emerge, and with them their related norms and conventions (Kress, 2003). This idea can be applied to the emergence of Instagram poetry, considered by some to be a subgenre within poetry (Pâquet, 2019). Some conventions of this subgenre include a lack of punctuation, capitalization, and excess use of enjambment, which is the breaking apart of an idea from one line into multiple lines (Pâquet, 2019). There is also use of multimodality: a pairing or tripling of text with images or sound. Many scholars and literary critics deem this poetry "lowbrow" because of a lack of academic language and the amateurism of the authors, whose claim to the title of poet only came through the amount of likes on their Instagram posts (Pâquet, 2019, p. 296). However, Pâquet argues that the severance from academic language makes the poems "immediate, genuine, and authentic" (Pâquet, 2019, p. 309).

Naji (2018) cautions against criticizing newer forms of poetry that look different from the traditional North American canon. She notes that the previous canon was dominated by white 
males and the current one is incorporating more diverse people and their experiences (Naji, 2018). There are systemic racial and patriarchal boundaries around poetry, and it would be folly to allow them to dictate what can be considered good poetry. She furthers this point by conducting a search on Instagram of the hashtag \#Instagrampoetry on April $4^{\text {th }}, 2018$ (Naji, 2018). Eight of the nine top posts in terms of popularity were created by females and contained female-centric content (Naji, 2018). Considering it could easily be said that this poetry is being criticized simply because it is feminine, it is important to keep in mind the sociocultural background of the critic as well as the poet due to the history of poetry in North America and to judge by fair standards. Gender and race are important factors to keep in mind when considering Rupi Kaur, the most famous Instagram poet who also has two print collections of her work published. She is a young Indian-Canadian woman who writes about love, sensuality, trauma, and healing (Pâquet, 2019). There is a large community who believes her work is not good enough to be called poetry, which is backed by many scholars and critics (Pâquet, 2019). However, her current following on Instagram is at four million, which is indicative of her work's economic and social success (Kaur, 2020).

Naji's concerns are by no means new. Dorothy Wang, poet and English professor, commented on the 2007 Publication for the Modern Language Association conference (Wang, 2013). This organization is extremely influential in canonizing North American work. Wang (2013) states that it is the "largest, most powerful and influential professional organization for professors and academic critics of literature..." (p. 1). Perloff, who gave the presidential address, echoes racist tendencies in literary criticism when she mentions by name several white poets, such as Virginia Woolf and Faulkner, but mentions only generally and in passing minority writers (Wang, 2013). To this Wang (2013) asks, "How is it possible that among nine poetry 
critics, speaking about poets across centuries and 'The New Lyric Studies', not a single poet of colour writing in English is cited" (p. 17)? Like Perloff, the other critics do not explicitly state any racist remarks, but there is a general consensus to approach literary studies in a more disciplined, theoretical manner rather than writing freely and about political and social topics, the latter of which is associated with non-white writing (Wang, 2013). Wang (2013) believes in both forms of writing. Further, she acknowledges the idea that works by non-white authors are part of the curriculum not because of their literary merit, but more to reach a "racial quota" (Wang, 2013, p. 7). Sociopolitical context weighs heavily on the form and content of poetry, and must be considered when comparing works.

With these social changes going on, communication mediums became more diversified and competitive. Two relevant and popular mediums for poetry during this time are poetry anthologies and other print collections as well as Instagram, a social media photo-sharing application. These mediums have much larger differences than periodicals and small magazines, mirroring the diversified society that they emerged from.

In the twenty-first century, competition between mediums no longer exists solely within print. With eBooks and the internet, poetry has become extremely accessible and inexpensive to read, putting print media in decline. However, poetry collections, both by multiple authors and single authors, still line the shelves of bookstores and offer an alternative to digitally mediated poetry. Their legitimacy and importance are emphasized by the two poetry collections published by Rupi Kaur (Pâquet, 2019). Following her rise to fame, Kaur published Milk and Honey, which sold three million copies globally and was translated into twenty-five languages (Berens, 2019). In fact, in 2017, 47\% of all poetry books sold in the US were written by Instagram poets and were featured originally on Instagram (Berens, 2019). Though Instagram poetry was created for 
Instagram, authors and publishers still want to make print collections of these works. This media crossover could mean two things: one, that Instagram poetry is not as profitable as book sales and Instagram poets can utilize their popularity online to sell books, and two, that print media, specifically poetry collections with a price tag, remains a way to legitimize and historicize works. Despite many of the poems in Milk and Honey being available on Kaur's Instagram page for free, three million copies of the book were sold, which indicates that the reading experience is different (Berens, 2019).

The concept of a certain legitimation and elitism attached to print works of poetry is not a new one, but stems back to the beginning of the twentieth century when poetry anthologies were "an overproduced commodity" (Collier, 2016). Despite the saturated market, poets and scholars found anthologies useful to their work, while the public typically bought and read them at a profitable rate (Collier, 2016). In fact, anthologies were one of the few ways poets could actually make money from their work (Collier, 2016). The Oxford Book of English Verse is a good example of a well-circulated anthology (Collier, 2016). Selling 250,000 copies between 1900 and 1939, it exceeded the sales of most single-authored poetry books during this time (Collier, 2016). It was meant to be more affordable than most anthologies, yet it was still priced too high for the "working-class readers", rendering it an exclusive medium that afforded its owners intellectual privilege (Collier, 2016). This idea transfers over to today, when many poems of contemporary authors are available online through free resources, such as the Poetry Foundation (digital descendent of the Poetry magazine), and yet readers will still pay for small collections of poems from authors they enjoy.

One of the most popular mediums of poetic dissemination in contemporary times is the social media application Instagram (Pâquet, 2019). The medium is radically different from 
nineteenth century periodicals and was made for very different reasons. Instagram fosters interconnectivity via the internet through photo-sharing, commenting, and liking, and the poetry produced through this application is produced specifically for Instagram (Pâquet, 2019). The application, then, is instrumental in the creation of this kind of poetry. Instagram poetry can vary, but it usually contains minimal text and is accompanied by an image or sketch (Naji, 2018). It consists of fairly generic and relatable sentiments which are written plainly and without traditional poetic style (Naji, 2018). For these reasons, critics and scholars have rejected Instagram poetry as void of literary merit (Naji, 2018). Rebecca Watts, critic in the PN Review, wrote, "The reader is dead: long live consumer driven content and the 'instant gratification' this affords" (Naji, 2018, p. 5). Her quote recalls a similar debate during the late twentieth century as periodicals mass produced small, straight-forward poetry which stifled the genius and creativity of real poetry (Brinkman, 2009). However, just as the consumer dictated content over a century ago, the consumer remains important, and possibly more so today. Instagram poetry may look very different from the American canonized poets, but it is circulated and consumed by millions worldwide, which would not be possible without the affordances of Instagram and the digital age.

As a social media application, Instagram promotes and facilitates participatory culture (Naji, 2018). Commenting, liking, sharing posts, and following accounts is what makes someone and their content Instagram-famous. In an environment such as this, it is unsurprising that what can result is "anthropophagic texts - cannibalistic texts that remix, reuse and re-appropriate content" (Naji, 2018, p. 1). Rather than appropriation having a negative connotation, in this setting, it is the norm. Instagram poetry must be easily relatable and shareable to enjoy success on an application like this. Naji (2018) goes on to say that "the interpretation of these works 
depends on reference to a network of participants" (p. 4). In this way, Instagram's affordances influence the content of poetry.

Most notably, Instagram is a dominantly visual social sharing application; users share content in the form of pictures (Naji, 2018). It is interesting that a new subgenre of poetry, which is usually strictly textual, became popularized through a photo-sharing application. This may be due to the poetry consisting of multiple modes of communication. It has been argued that Instagram poetry is much more than a few short, simple lines; it also consists of the aesthetic appeal of posts as well as non-verbal posts surrounding it, and the overall branding of the Instagram poet (Pâquet, 2019). The entire page of the Instagram poet becomes part of the poetry, making the work multimodal in nature. Posts which contain only text can also be multimodal (Kress, 1998). Kress argues that even taking text from paper and translating it identically onto a computer or phone screen will change the way the information is received in that it becomes more visual (Kress, 1998). Echoing his ideas are Goodman and Graddol (1997), who state that words are also shapes, and the mind pays attention not only to what is written but "how it is written", that is, in a visual sense (p. 42). Text becomes increasingly visual when typefaces are considered (Goodman \& Graddol, 1997). In their words, "The connotative potential of typography suggests that content and form are inextricably linked" (Goodman \& Graddol, 1998, p. 47). When a screen is involved, especially on a visual photo-sharing app, text-based posts must be considered equally visual.

Due to the evolution of the internet coupled with mobile devices, multimodality is almost exclusively the way in which information is now shared. Serafinelli (2018) discusses the affordances of these technologies in terms of how they relate to the popularization of Instagram, a dominantly visual social medium and the dissemination tool of the most popular poetry in 
current contemporary times. Multimodality offers flexibility in meaning and interpretation, however, it can also confuse meaning and make interpretation much harder (Kress, 1998). Kress also argues that text is reliant upon time in that it must be read in sequence, while image is reliant upon space, typically with more important information in the centre rather than the margins of a screen or page (Kress, 2003). Images, he continues, are "plain full with meaning" while the meaning of writing waits to be filled by the reader (Kress, 2003, p. 4). Put another way, images are "the world shown" and text is "the world told" (Kress, 2003, p. 1). Kress (2003) states that "the logic of the screen allows multiple points of entry", while text only allows one (p. 1). Kress is ultimately saying that image recognition requires a different literacy than reading text, and combining the two requires an entirely new literacy (Kress, 1998). Visual information takes less time to interpret than words due to associative meanings of icons and other symbols (Kress, 1998). Though meaning-making through images may be quicker than words, it allows for a wider interpretation due to different associations with images (van Leeuwen, 2004).

In the study of semiotics, understanding icons requires an understanding of cultural context (van Leeuwen, 2004). In visual semiotics, there are two layers of meaning; denotation and connotation (van Leeuwen, 2004). Denotation refers to what or who is literally being depicting, while connotation refers to the ideas or values being represented by the image (van Leeuwen, 2004). Considering Instagram houses millions of users globally that have vastly different experiences and cultural understandings, incorporating a large amount of images or visuals into poetry may cause very different interpretations. However, this trait in Instagram poetry is likely what makes it so popular; what is depicted is always a universal, general experience that can be interpreted by the largest audience possible. Kress (2003) notes that when text is accompanied by images, the visual element of information will be elevated at the expense 
of the textual. Szabó (2016) echoes Kress in his observation that visual text indeed has equated and sometimes dominated the process of written text. Again, for users on Instagram who may not speak English or have other barriers to textual literacy, a stronger sense of understanding through images may benefit them, thus bolstering the popularity of Instagram poets and poetry.

Poetry anthologies and Instagram are extremely different mediums for disseminating poetry, and will therefore promote or discourage certain genres and styles of poetry based on their capabilities. Poetry anthologies are print-based and textual. They contain poems chosen by critics and editors, while Instagram poems are digital and multimodal, the most successful content being determined by likes and follows awarded by Instagram users worldwide. With this in mind, poetry published through anthologies typically tend to be longer and less generic in content, while Instagram poems are far shorter and relatable.

Poetry, like many artforms, is inextricably linked to subjectivity. Also subjective and contested are diverging theories on what constitutes poetry. Many have been discussed in this section in order to include a wide scope of work under the definition of poetry. Cultural context is vitally important to understanding how and why poetry shifts in form and content. It is for this reason that the communication mediums discussed were framed within this context. However, communication mediums themselves can afford much change to poetry, a change that is separate from sociocultural influence. This is true based on the widely differing popular forms of communication mediums that were circulated within the same time periods. In each case, the medium dictates what can be contained within it, which will restrict and promote certain aspects of poetry. 


\section{Methodology}

\section{Research Question}

The following research question and sub questions will help determine the relationship between communication mediums and poetry over time:

1) What differences are there in form and content between poems published in different North American communication mediums across two distinct time periods?

a) How do poems in periodicals compare to poems in small magazines that were published in October of 1912 ?

b) How do poems in anthologies compare to poems on Instagram that were published between September and December of 2014?

c) How can quantitative data of poetry content and qualitative data of poetry structure indicate these differentiations?

This research question is fundamentally interested in how a communication medium might influence popular poetry, both in subject matter and in structure, and both synchronically and diachronically. In order to rule out cultural context as an influence on poetry's evolution, each medium is compared with a contrasting medium within the same time period, as specified in parts A and B of the research question. Two time periods were chosen (October of 1912 and September to December of 2014) to look at poetry's change over time as well as change in the mediums used to circulate it. Part C indicates the methods used to detect and measure these differences, which focuses on content and form. Content can be assessed by type-token ratios, word frequency, and word distinctiveness, while form can be assessed using qualitative questions 
about the visual layout that include factors such as poem placement, multimodality, and grammar.

\section{Data Selection Process}

Periodicals were a popular medium in the nineteenth and twentieth centuries (Brinkman, 2009). Of this genre, The Atlantic, Harper's, and The Century were the most prominent (Brinkman, 2009). Harper's was selected as the periodical for this study because of its prominence and its accessible digital archive through the Ryerson website. Poetry is the little magazine used for this study. It was chosen for its innovation, as it was created as an alternative for poets who were frustrated with the limitations of periodicals (Brinkman, 2009). It also overlapped in publication with Harper's. The $125^{\text {th }}$ volume of Harper's was selected to be compared with poems from the first volume of Poetry, as they were published within the same month: October of 1912. This date also historically marks modern poetry's inception in North America (Newcomb, 2004).

A poetry anthology was selected as an alternative print medium to compare with Instagram poets. The Best American Poetry 2014 was chosen for its popularity and longstanding publication. Though it only contains American poets, the group is very culturally diverse, much like Canadian poets. The text contains seventy-five poems, all by different authors. It was also selected for its publication date: September $9^{\text {th }}, 2014$. Two months after, Rupi Kaur's Milk and Honey print collection of Instagram poems was published, representing when Instagram poetry and poets began amassing large amounts of popularity (Berens, 2019). Therefore, poems pulled from Instagram also had to have been published between September and December of 2014 in order to compare works within a nearly identical sociopolitical context. 
Five poems from each medium were selected for a quantitative analysis, making up a total of twenty poems. For an additional qualitative analysis, one poem from each of the five was selected, making a total of five. The number five was chosen as a manageable amount for the scope of this paper, and a total of five poems are present in the $125^{\text {th }}$ volume of Harper's. In order to have equal representation from all mediums, five poems were selected from all other mediums. Poetry also contained the poems of five poets, with two poems coming from Ezra Pound. One was randomly selected. The Best American Poetry 2014 anthology contained seventy-five poems. To avoid bias in selections, the poems were split into two groups: those written by females and those written by males. Each poem was numbered in each group, and the entire seventy-five poems were also assigned a number. Using a random number generator, two poems were selected from the female group, two from the male, and one from the entire group. This was done to ensure equal gender representation, as the female group only amassed twentynine poems of the anthology, while the male group made up forty-six. Instagram poets were selected based on their popularity, which was assessed by their number of followers. Those selected also had to have poems posted within the date range of September 2014 to December 2014. Each poet had over one million followers, with the exception of Cleo Wade at 605,000. Poems (or posts) were selected based on their proximity in publication date to September $9^{\text {th }}$, 2014, the date The Best American Poetry 2014 was published.

Through this selection process, the following poems were chosen from Harper's: Richard Le Gallienne's “Land of Rain”, Anne Bunner's “O Wise and Strong”, Ellen Glasgow's “Song”, George Philips' "Wonder Song", and Florence Earle Coates' "In the Town a Wild Bird Singing". The following poems were chosen from Poetry: William Vaughn Moody's "I am the Woman", Ezra Pound's “To Whistler, American”, Emilia Stuart Lorimer's "Fish of the Flood”, Helen 
Dudley's "To One Unknown", and Grace Hazard Conkling's "Symphony of a Mexican Garden". Poems from The Best American Poetry 2014 include: Harryette Mullen's "Selection from Tanka Diary”, Cate Marvin's “An Etiquette for Eyes”, Afaa Michael Weaver's “Passing Through Indian Territory”, Cornelius Eady's “Overturned”, and Jane Springer's “Forties War Widows, Stolen Grain". Poems selected from Instagram are posts and do not have titles. Their authors are Atticus, Rupi Kaur, R.M. Drake, R. H. Sin, and Cleo Wade.

For the qualitative analysis, poems were selected based on how well they represented the other poems in their group. The following considerations were taken: type-token ratio (explained further below), number of words, how many terms it shared with poems from that medium, and how many terms it shared with poems from all mediums. These considerations were selected based on works by Jacobs (2018), Kress (1998), and Brinkman (2009). Poems with closer numbers to the average of that group of poems were given more consideration. Equally, poems were chosen based on how they visually represent the rest of the poems from their medium in terms of formatting. Based on these criteria, "Wonder Song" From Harper's and "Symphony of a Mexican Garden" from Poetry were chosen as well as "An Etiquette for Eyes" from The Best American Poetry 2014 and Atticus's poem from Instagram.

\section{Approach}

To answer the research questions, a mixed method research approach has been taken. The content of the selected poetry has been analysed using Voyant-tools.org in order to reveal similarities and differences in diction and subject matter across all four mediums of poetry (Sinclair et al., 2016). Voyant-tools.org is a digital tool used by researchers for textual analysis

(Sinclair et al., 2016). The tool was used to quantify the number of terms used in each poem as well as their unique terms, the type-token ratio, distinct terms, and shared terms between poems. 
In order to eliminate the variable of sociopolitical context, three separate corpuses were created based on dates. The first includes the poems from the twentieth century, found in Harper's and Poetry. The second includes poems from the twenty-first century, found in The Best American Poetry 2014 and Instagram. The last includes all poems from all mediums to check for crosscultural similarities across the two time periods selected.

Voyant was used to measure vocabulary density or lexical diversity, word frequency, and word distinctiveness. Vocabulary density/lexical diversity refers to the number of types of words in each poem of each medium divided by the number of total words, also known as the typetoken ratio (Jacobs, 2018). According to Jacobs (2018), this ratio can indicate "linguistic complexity, poetic quality, or esthetic success" (p. 6). Typically, a higher ratio is indicative of a more complex poem of higher quality (Jacobs, 2018). The total wordcount is also a method of measuring the length of each poem, which, when associated with the medium, can indicate the capacity in terms of poem length for that medium. In other words, a medium that contains poems with a higher wordcount allows for more space for poetry. This is a way to test if Harper's, a periodical, truly gave less space to poetry than Poetry, the small magazine, as indicated by Brinkman (2009). Word frequency refers to the number of times the same word appears in a poem (Jacobs, 2018). This can indicate the typical vocabulary used in a single poem or across an entire medium. Word frequency will also indicate the shared terminology across all mediums when analysing all twenty poems together. Shared terminology may point to patterns in terms of themes in poems across mediums and across the two time periods. Word distinctiveness refers to words found only in one text, author, or group of work (Jacobs, 2018). It can also indicate the vocabulary or themes of a poem or a medium. These three tools help to assess the content of 
each poem and each medium, offering a means of comparison between mediums to answer the question of how they may differ in content.

To understand how form has changed over time, a qualitative approach was taken. A close analysis was conducted using several questions about the visual appearance of each poem. A poem from Harper's and Poetry will be compared, followed by a poem from The Best American poetry 2014 and Instagram poets, and lastly, a brief analysis was done across all four poems. The following were considered when visually appraising each poem: the poem's location on the page, whether or not it extended to multiple pages, what else was present on the page, whether or not the border of the poem was clear, if the poem was multimodal, if any visual meaning could be gleaned from the poem's text alone, typography, and the use of punctuation and capitalization. These questions were developed to best understand how the medium's format is being utilized and if it is allowing or restricting certain formatting in poetry. Excel was used to organize all findings. 


\section{Findings}

\section{Quantitative Results}

Voyant Tools and Excel were used to answer the portion of the research question that asks how the content of poetry differs between Harper's and Poetry as well as The Best American Poetry 2014 and Instagram from a quantitative lens.

\section{Vocabulary Density: Wordcount and Type-Token Ratios}

\begin{tabular}{|lcccc|}
\hline Table 1 & & & \\
Elements of Vocabulary Density of All Mediums & & \\
\hline Medium & Average Wordcount & Total Wordcount & Average Type-Token Ratio & Range \\
\cline { 2 - 5 } Harper's & 143.6 & 718 & $64.6 \%$ & $52-288$ \\
Poetry & 452.4 & 2262 & $62.4 \%$ & $71-1088$ \\
The Best American Poetry & 194.2 & 971 & $69.4 \%$ & $62-232$ \\
Instagram & 21.6 & 108 & $88 \%$ & $10-40$ \\
\hline
\end{tabular}

Vocabulary density involves wordcount and type-token ratios. A discussion on average wordcount, total wordcount, range of wordcount, and average type-token ratio is important when considering this measurement. The total words for each medium were assessed by creating four separate corpuses; one for each medium. Average wordcount in Table 1 is the total number of words in each poem of the medium divided by the amount of poems in the medium ( 5 per medium). The total wordcount refers to all words of all five poems per medium, and the range is the poem with the least amount of words to the poem with the most amount of words per medium. The wordcount for each medium is fitting with what the literature predicted. Brinkman (2009) mentions that popular periodicals in the nineteenth and twentieth centuries were not bought for their poetry, but for their journalism, pictures, and stories. Harper's has the second least total wordcount of the four mediums, which is indicative of little space in the medium for 
poetry. Also unsurprising is Poetry, which was revolutionary in its acceptance of unorthodox verse, longer poems, and poem-only content (Brinkman, 2009). Poetry has the highest wordcount by far, which indicates more space allotted to poetry. The Best American Poetry 2014 had a comparably smaller wordcount, but it is important to remember that many poems in this publication were excluded from this study. The range in poem length helps compensate for the exclusion of these poems by revealing the typical length of a poem in each medium. Instagram has the fewest words, which may indicate the presence of images rather than words, in keeping with Kress' (1998) note on twenty-first century media becoming increasingly visual.

Wordcount also helps to answer the part of the research question that is interested in how mediums compare within one time frame and over two time frames. It indicates that in both time periods, there is one medium with a significantly lower average wordcount than the other medium. In October of 1912, Harper's has comparatively shorter poems than Poetry, and between September to December of 2014, Instagram has drastically shorter poems than The Best American Poetry 2014. This indicates a diversity in communication mediums within both time periods, and across both time periods. In either time frame, there were communication mediums that accepted shorter poems and longer poems. However, the communication medium with the higher wordcount from 1912 (Poetry) is significantly higher than the communication medium with the higher wordcount from 2014 (The Best American Poetry 2014). Similarly, the communication medium with a lower wordcount from 1912 (Harper's) is much higher than the communication medium with a lower wordcount from 2014 (Instagram). This indicates a shortening of poem length over time, and may be related to Kress' (1998) thoughts on multimodality in that the genre is opening up to non-text-based ways of communicating. 
The average type-token ratio is the number of unique terms (or tokens) in a poem divided by the number of total words in a poem. All five poems of each medium were added and then divided by five to get the total average type-token ratio per medium, which is the number indicated in Table 1. When recording these results, a pattern emerged: mediums with high wordcounts tended to have a lower type-token ratio, indicating a trend wherein poems with more words have fewer unique words than poems with less words. According to Zipf's law, there is an "equilibrium" between the length of a poem and how frequently the same type of word appears (Jacobs, 2018, p. 1). This means that poems usually strike a balance around 50\% in their typetoken ratios. This is generally true for three of the four mediums: the average ratio hovers within the $60 \%$ range, which, according to Jacobs (2018), indicates a good linguistic complexity. Instagram is the exception.

Based on their average ratio of $88 \%$, Instagram poems break Zipf's law by having a very high lexical density (Jacobs, 2018). This is unusual for poems, and also should indicate a high level of linguistic complexity, however, when considering the length of Instagram poems, this number is less of an anomaly. Because poems typically aren't as short as one sentence, typetoken ratios should be a good indicator of vocabulary density or lexical diversity and possibly even quality of a poem, but in the case of Instagram poems, the short length of the poems interfere with this indicator. Jacobs (2018) assessed the lexical diversity of poems almost exclusively from the nineteenth century. He states this as a limitation of his study, and mentions in his concluding remarks that his approach and the results of his study may not be "appropriate for studies using more modern or contemporary prose and poetry texts" (Jacobs, 2018, p. 9). Instagram poetry, like many genres in the arts, is multimodal, making it impossible to assess poem quality through lexical diversity alone. As discussed in the literature review, multimodal 
and dominantly visual communication has become the norm in current society, an opinion expressed by Kress (1998), Szabó (2016), Naji (2018), and Pâquet (2019). If the poem is made up of more than a lexicon, then vocabulary density is not an adequate way of assessing poetry quality.

Linguistic complexity of poems in each medium, which is also indicated by vocabulary density, is not a good indicator of repetition or similarity of ideas (Jacobs, 2018). According to their type-token ratio, Instagram poems have the highest linguistic complexity, while poems from Poetry have the lowest. This may be true on an individual linguistic level, but further methods of analysis show that the content of Instagram poems tends to be far more generic than the content of Poetry poems. Though there are few shared terms between Instagram poems, sentence structure and theme are strikingly similar across all poems. This is not the case with poems in Poetry. Four of the five Instagram poems are written about a female(s) in regards to their beauty, importance, and empowerment. Three of the five poems are written for a nameless female in an effort to defend her character and honour. For example, Rupi Kaur's poem begins with, "she was music..." (Kaur, 2014), and R. M drake's poem begins with, "she was thunder..." (Drake, 2014). R. H Sin's poem starts in a similar vein: "but you were supposed to protect her mind..." (Sin, 2014). In each instance, the female in question is not the speaker, but is being referred to in the third person. Therefore, she is not advocating for herself. The only poem that does not mention a female character or characters is Atticus's poem (Atticus, 2014). These Instagram poems have very few words, which means they have a high number of unique terms, making the repetition in terminology between them very low. However, this is not because they do not share ideas, but because they are so short. The notion of shorter poems being more generic in content is one stated by Brinkman (2009) and mentioned in the literature review. 
Brinkman (2009) states that "the short form perhaps most easily leant itself to what has been called 'light verse'...” (p. 25). Here, he is referring to periodicals, which were also short in order to fit into the structure of the periodical and make room for the other content that the periodical sold for (Brinkman, 2009). However, based on these findings, his thoughts can be applied to Instagram poetry as well.

\section{Word Frequency and Word Distinctiveness: Shared and distinct terms}

For this study, word frequency refers to how often a specific word appears in a corpus. This was measured both within each poem of a medium to assess similarity in content and themes, between two mediums within the same time period, and across all four mediums. Each word is only counted once when it appears in one poem, even if it appears several times. This was done to get a clearer understanding of shared terms between mediums rather than the vocabulary of a single text. However, the Excel spreadsheets in Appendix A tally the amount of times the word appears per poem. Word frequency was meant to highlight similarities in content between poems from different mediums, both within a time period and across both time periods, which refers to the part of the research question regarding content. The results indicated very little similarity in terminology over the four mediums, little similarity between the twenty-first century mediums, and some similarity between the twentieth century mediums.

Between poems from Harper's and Poetry, shared terms include "heart", "little", "dream", "moon", and "star". "Heart" appears in four of the five poems from Harper's and three of the five poems from Poetry, "little" appears in three of the five poems from both mediums, "dream" is in three of the five poems from both mediums, "moon" is found in two of the five poems of each medium, and "star" is found in three of the Harper's poems and two of the Poetry poems. These terms indicated themes of love and nature, and more specifically pointed to 
celestial imagery between the two themes. Even less terminology overlaps between poems from The Best American Poetry 2014 and Instagram. "Things" and "love" are the only shared words. "Things" is present in two of the five poems from the anthology, while it only appears in one poem of the Instagram poems. "Love" is present in one of the five anthology poems and three of the five Instagram poems. There are not enough shared terms to indicate any sort of similarity in theme across these mediums. The same is true across all four mediums, which only shared one word: "things". This word appears in one poem from Harper's, two poems from Poetry, two poems from Best American Poetry 2014, and one poem from Instagram. The word itself is so broad in terms of definition and use and also appears very few times across all mediums, making it unhelpful in determining shared themes. It is important to note that little can be gleaned about the significance of each term without a reference corpus, which is necessary to identify key terms. It is beyond the scope of this study.

Therefore, word frequency revealed little similarity in content between poems of different mediums. Considering the changes in poetic movements and sociopolitical context, it is not surprising that vocabulary changed drastically between 1912 and 2014. However, it is surprising how few words poems from Instagram and The Best American Poetry 2014 shared given that they were also published within the same time period. This may be due to a diversification in culture and experiences, and what is accepted into the canon. As noted in the literature review, racial segregation and preference still persists within the poetry canon in the twenty-first century (Wang, 2013), but technology and multimodality as well as political change allows for diversified content (Kress, 1998). Another possible reason is the extremely short length of Instagram poems, which also relates back to type-token ratios. Because they are so 
short and most words are unique, there is less content to be compared with the poems from the anthology, making shared terminology less likely.

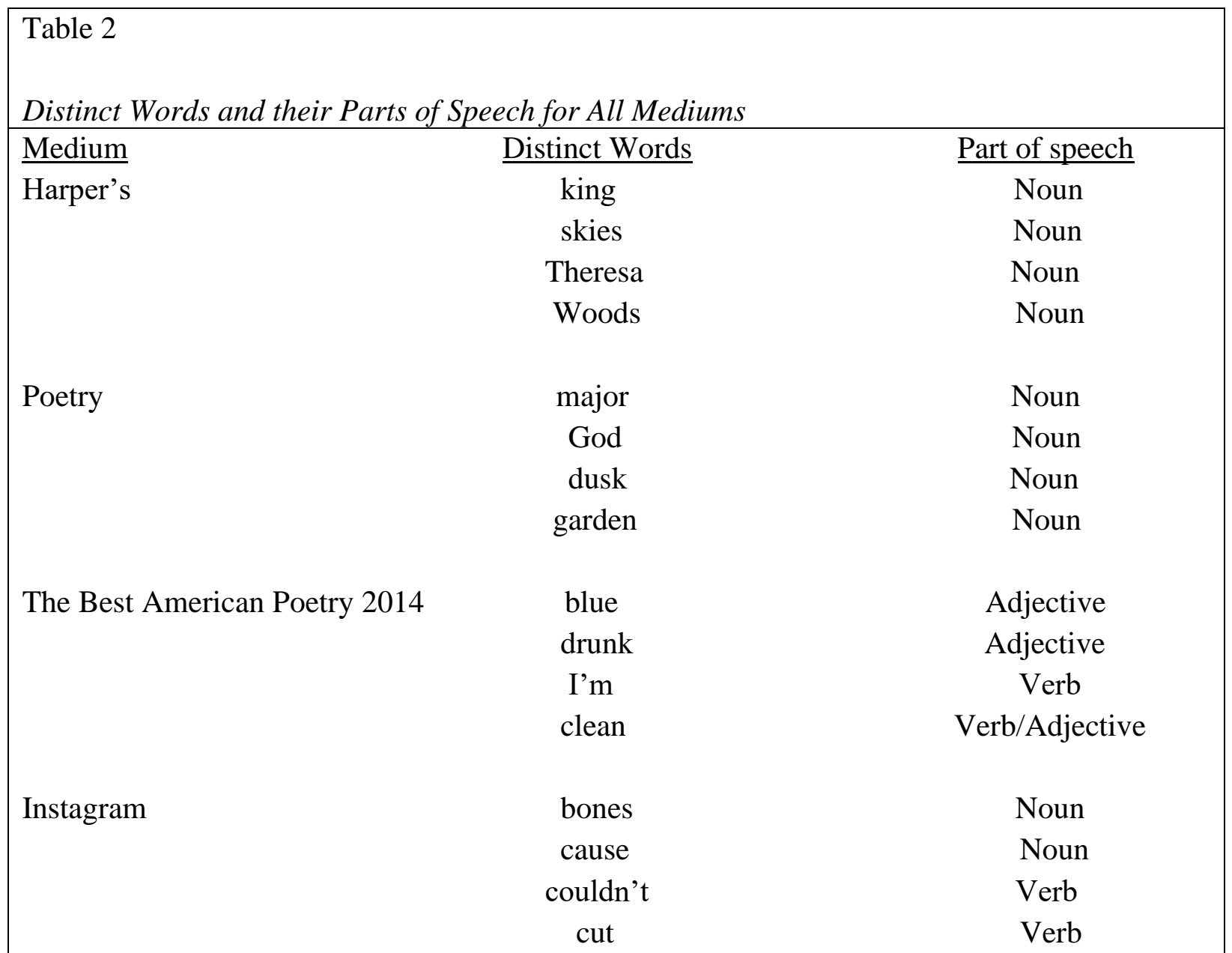

Word distinctiveness was found by analysing each medium in a separate corpus and cross-referencing each medium with one word from the medium in question to make sure it did not appear. This was done with the top four most frequent words in each medium's corpus.

Distinctive words from Harper's poems included "king", "skies", “Theresa", and "woods". From Poetry, "major", "god”, “dusk”, and "garden”. From The Best American Poetry 2014, "blue”, “drunk", “I’m”, and “clean”. Lastly, from Instagram, "bones”, “cause”, “couldn’t”, and "cut”. Because of how few poems are included in this assessment, there is little that can be said about 
the vocabulary of each medium. Another limitation to keep in mind is that not all poems from each medium are included. All poems from Harper's are included, all but one from Poetry are included, but 70 of the 75 poems from The Best American Poetry 2014 are not included, and many poems from Instagram are not included. Therefore, words that are distinctive to each medium may not actually be distinctive, especially when considering that most words in each Instagram poem are distinctive due to its high type-token ratio. Also, the distinctive words in a medium tend to come from the longest poem from that medium, which points yet again to the effect that length has on analysing poetry. However, what can be observed based on these findings is that contractions do not appear in the list until the twenty-first century and nouns dominate the distinctive words in the twentieth century, while the twenty-first century mediums contain a mixture of nouns, adjectives, and verbs. The contractions may be indicative of an informalization of language, a trend noted by Kress (1998) that occurred in the late twentieth century. The word distinctions illuminate a trend within time frames of mediums and also show differentiation between each medium, which helps to answer the part of the research question concerned with trends in mediums over time.

Measuring vocabulary density through wordcount and type-token ratios confirmed that more space was allotted to poems published in Poetry than Harper's. It also confirmed that most poems tended to keep an "equilibrium" between poem length and unique words, with their typetoken ratio hovering around $60 \%$ (Jacobs, 2018, p. 1) Instagram poems were the exception, which is indicative of their content being multimodal, or in other words, not strictly linguistic, and therefore impossible to measure with linguistic tools alone. Instagram may be considered to foster poems with high vocabulary density based on this measurement, but Instagram poem length interferes with the measurement. Length proves to be an important element when 
considering vocabulary density, word frequency, and word distinctiveness, making it difficult to measure Instagram poems alongside other print-based poems. Based on the quantitative data, content is affected by the length of poems, which is dictated by the medium the poem is in, and it is also diverse across each medium, even within a small time frame.

\section{Qualitative Results}

A qualitative approach was taken in the form of a visual analysis to assess the portion of the research question that asks how poem formatting differs between each medium. Poems chosen for assessment include "Wonder Song” by George Philips from Harper's, "Symphony of a Mexican Garden” by Grace Hazard Conkling in Poetry, “An Etiquette for Eyes” by Cate Marvin from The Best American Poetry 2014, and Atticus's poem from Instagram. Each poem was assessed based on its placement, visual elements, grammar, and typography. Brinkman (2009) notes that the meaning of a poem can change when juxtaposed with other information on a page, such as cartoons, politics, or jokes (Brinkman, 2009). This was a common occurrence in periodicals like Harper's. His observations are aligned with Kress's thoughts on multimodality (Kress, 2003). Sharing space with anything other than the text in question will change the way information is taken in by the reader (Kress, 2003). This causes the contents of a page as well as what is considered to be the border of a poem very important to understanding the poem. When visuals are added, this must also be taken into consideration. Even text can be multimodal depending on what it is being displayed on, and how (Kress, 1998). Grammar was taken into account because of Kress's (1998) note on a shift in informality with time. Also related to informality is typography. Goodman and Graddol (1997) state that "the typeface in which a text, or part of a text, is set can convey vast amounts of connotative meaning - it can convey a mood, signal clues as to content or even suggest a point of view" (p. 43). These methods offer a way to 
compare the visual layout of poems across mediums. For reference, all qualitative poems can be found in Appendix C.

\begin{tabular}{|c|c|c|c|c|c|}
\hline Category & Question & "Wonder Song" & "Symphony of a Mexican Garden" & "An Etiquette for Eyes" & Atticus \\
\hline \multirow{3}{*}{ Medium } & Type & Print & Print & Print & Digital \\
\hline & Name & Harper's & Poetry & Best American Poetry 2014 & Instagram \\
\hline & Type of access & $\begin{array}{l}\text { Digital: online archive } \\
\text { access }\end{array}$ & Digital: online archive access & Digital: online Ebook & Digital: internet \\
\hline \multirow{4}{*}{ Placement } & $\begin{array}{l}\text { Where is the poem located on the } \\
\text { page/screen? }\end{array}$ & $\begin{array}{l}\text { Middle of the page, } \\
\text { slightly lower than the } \\
\text { centre. }\end{array}$ & Middle centre of each page it is on. & Left-justified on both pages. & Middle-left of the post. \\
\hline & Is it the only work on the page? & No & Yes & Yes & No \\
\hline & What are the borders of the poem? & $\begin{array}{l}\text { The poem is bordered } \\
\text { by an invisible rectangle } \\
\text { rather than the page, as } \\
\text { there is the end of a } \\
\text { prose piece also on the } \\
\text { same page. }\end{array}$ & $\begin{array}{l}\text { The poem's borders extend beyond } \\
\text { the first page and is encompassed } \\
\text { by multiple pages ( } 7 \text { ) }\end{array}$ & $\begin{array}{l}\text { The poem's borders extend } \\
\text { beyond the first page and is } \\
\text { encompassed by multiple } \\
\text { pages (4) }\end{array}$ & $\begin{array}{l}\text { The poem's borders can be } \\
\text { understood as the borders of the } \\
\text { Instagram post, but also can be } \\
\text { understood as non-existent if the } \\
\text { poet's Instagram page is } \\
\text { considered part of the poem. }\end{array}$ \\
\hline & Are the borders clear or undefined? & Clear & Clear & Clear & Unclear \\
\hline \multirow[t]{2}{*}{ Visual aspects } & $\begin{array}{l}\text { Is the poem multimodal? (Contains } \\
\text { modes other than text) If yes, what } \\
\text { mode, and what is being depicted? }\end{array}$ & No & No & No & $\begin{array}{l}\text { Yes, images: four full pictures can } \\
\text { be seen in the screenshot of } \\
\text { Atticus' page. All four are in black } \\
\text { and white. One is of an upside } \\
\text { down shot of a young shirtless } \\
\text { man with a cigarette balanced on } \\
\text { his nose. The next is a young } \\
\text { woman against a blurred } \\
\text { background of trees with long } \\
\text { hair whisping in the wind. } \\
\text { Another is of a couple in bed } \\
\text { holding each other with stacks of } \\
\text { books on a shelf above them, } \\
\text { and another is of the night sky } \\
\text { with the back of a truck and two } \\
\text { peoples' legs visible. }\end{array}$ \\
\hline & Is the text visual? & No & Yes & Yes & No \\
\hline \multirow[b]{2}{*}{ Grammar } & Is punctuation used? & Yes & Yes & Moderately & Yes \\
\hline & $\begin{array}{l}\text { Is the beginning of each line } \\
\text { capitalized? }\end{array}$ & Yes & Yes & No & No \\
\hline Typography & $\begin{array}{l}\text { Is the typeface used serif or sans } \\
\text { serif? }\end{array}$ & Serif & Serif & Serif & Serif \\
\hline
\end{tabular}

\section{Poem Placement}

Poem placement includes where the poem is located on the page or screen, whether it is the only piece on the page, what the borders of the poem are considered to be, and whether or not those borders are clear. All three print-based poems were centred in the middle of the page, with "Wonder Song" from Harper's pushed slightly downward from the centre because of the end of another piece at the top of the page. Atticus's poem is centred within the post if considering the post to be the border of the poem. Poem placement on a page is important when considering "points of entry" (Kress, 2003, p. 1). These are where the reader begins to read a text, or when and where they begin to make sense of what they are seeing. When reading words, there is only 
one point of entry, as in North America we read left to right, top to bottom, and can only take in one idea at a time, while images have multiple points of entry, as we can see more than one thing on a page and produce meaning from those visualizations (Kress, 2003). Where the piece is, what modes of representation are used in the piece, as well as what other pieces are next to the piece changes the readability and even the understanding of the piece (Kress, 2003). "Wonder Song" shares the page with the end of a prose piece, which is split into two columns at the top of the page (see Appendix $\mathrm{C}$ for pictorial references). Because the prose piece is at the top centre of the page, the eye is drawn first to that chunk of text rather than the poem. This choice by Harper's is indicative of a lack of space given to poetry, most likely due to poetry not providing the main source of revenue (Brinkman, 2009). Atticus's poem is the only other poem that also has other pieces on the screen, if considering the borders of the poem to be unclear and beyond just the post itself.

"Symphony of a Mexican Garden" from Poetry and "An Etiquette for Eyes" from The Best American Poetry 2014 span multiple pages, do not have any other pieces on those pages, and are contained within those pages. Therefore, their borders can be considered the seven pages "Symphony of a Mexican Garden" occupies and the four pages "An Etiquette for Eyes" occupies. "Wonder Song" in Harper's has a border smaller than the page, because the page contains another piece. It is contained by what could be called an invisible rectangle that fits around the poem. These borders are fairly clear and distinctive. However, the Instagram poem doesn't seem to have a border, or at the very least, it is unclear. Atticus's poem is contained by the post, but can be viewed several ways: on a cellphone through a user's Instagram feed (which is most likely the case), on the Instagram page of Atticus, or via a share through an entirely different internet application. Instagram authors are aware of these methods of viewing; they 
know their work will be taken out of the context of their page, as most of them sign their names in their posts. There is also an awareness of the reader visiting their page and not just reading their poems through a user's feed. This is clear from the screenshots taken of the Instagramers' pages with each poem post imbedded within them. (These screenshots can be found in Appendix B. All screenshots are taken from the application version of Instagram on a cell phone, which is most likely where users view the content.) The pages range in terms of curation, but an author like Rupi Kaur shows a high level of curation on her page, with poems and portraits/images alternating to create a kind of visual poem throughout her page (Kaur, 2014). In all scenarios, Instagram poems share the screen with other content. Instagram, the only digital medium, also had the lowest wordcount of all the mediums, indicating a lack of space for text.

\section{Multimodality}

Multimodality can be present within one mode, such as text (Kress, 1998), however, when interpreting multimodality to refer to multiple methods of communicating, only one poem is multimodal, which is Atticus's from Instagram. When considering the border of his poem to be just the post, Kress argues that even this is visual rather than textual. He states that simply transferring text onto a screen elevates the visual aspect above the textual, no matter what is being depicted (Kress, 1998). Considering the poem is posted using a photo-sharing application, it is unsurprising that the poem might be viewed visually rather than read first. However, if considering Atticus's page to also be part of his poem, then images are also being employed. Surrounding pictures include four photos in black and white depicting a young white male with a cigarette, a young white female in the woods with long hair, a young white couple in bed beside books, and a starry sky with a pickup truck and two pairs of legs depicting a couple in the back (Atticus, 2014). Brinkamn (2009), when referring to the cluttered pages of twentieth century 
periodicals, mentions how meaning can change in a piece when other content is surrounding it. The same concept can be applied here with the images. These images, then, juxtaposed with the poem, can transfer meaning to it and hinder the reader's imagination of what and who is being depicted based solely on the words of the poem. For example, the poem simply reads, "Real depression / is when you stop doing the things you love" (Atticus, 2014). Perhaps for Atticus, the things he loves may be referring to photography, a romantic interest, reading, or nature, based on the images surrounding the poem. For readers who may not identify with these things or perhaps are not white, this visual interpretation could be contrasting to what they imagined or would have imagined if the visuals were not present. Further, if a user is viewing this poem through Atticus's page, he or she would see these images and possibly focus on them and their visual meaning more than the poem. Szabó (2016) also mentions that when text and images are placed together, the image will not just equate but dominate the meaning of the text. In terms of multimodality, the affordances of different mediums can drastically change the formatting and therefore the understanding of poems.

\section{Visual Elements of Text}

Text is full of visual meaning (Goodman \& Graddol, 1997). The visual symbols used to convey meaning cannot be divorced from the meaning of words themselves. Not only is text visual, but text placement and organization can be manipulated to take on certain visual meaning. For example, certain genres of writing can easily be identified just by looking at the form of writing before reading the content. A poem typically has stanzas of similar length, while prose and journalistic writing typically have paragraphs and blocks of text. This is true for "Wonder Song", which adheres to traditional poetic standards by having several stanzas of similar length (Philips, 1912). Beyond the recognition of genre, the text is not doing any visual work. 
Text can also change the way a reader takes in information. A great example of this is “An Etiquette for Eyes" from The Best American Poetry 2014. This poem has two distinct shapes in terms of stanza size and line length which include short, three-to-four-word lines that make up three-line stanzas, and larger blocks of text which have stanzas about eight lines each (Marvin, 2014). In both cases, the poem is left-justified and slightly off-centre (Marvin, 2014). The poem opens with the shorter stanzas, moves into thicker stanzas, and back to shorter stanzas, making a jarring shape and changing the pace at which the poem is read (Marvin, 2014). The three-word stanzas read quickly, but jaggedly, as the sentences are cut off at odd places through the use of enjambment, which is when a sentence in a poem extends over multiple lines. These stanzas look closer to the poetry genre than the longer eight-line stanzas, which more resemble blocks of text and look like prose. The larger groups of words also slow down the reading process and eye movement, as the reader needs to spend more time on each line than they did with the three-line stanzas. Beyond pace, visually, the poem is interesting, as it varies in shape.

"Symphony of a Mexican Garden" is also visual in its text, much like "An Etiquette for Eyes." The formatting of the poem mimics a musical symphony, much like the contents (Conkling, 1912). The form, then, is married to the content. The first page contains a sort of table of contents, where the different movements, or parts of the poem, are titled with their subsequent tempo indications (Conkling, 1912). It also looks like the opening page of a play with four acts, or the table of contents of a book, complete with a dedication at the bottom. At first glance, some of this is communicated immediately. The rest of the pages have blocks of text, possibly conveying the idea of a page dense with music notation. This poem, like "An Etiquette for Eyes", is very visually interesting without employing images. "Wonder Song" and Atticus's 
poem convey little to no visual meaning in their text. They are also the only mediums that have other pieces juxtaposing the poems.

\section{Grammar and Typography}

Also important to consider is grammar, including the use of punctuation and the adherence to standard poetic norms from a written perspective, as well as typography. Traditionally, poems will contain punctuation, and the beginning of each new line will start with a capitalized letter. Poems also tend to be typed in serif fonts, the most common being Times New Roman. Typefaces have a lot of influence on content meaning, as noted by Goodman and Graddol (1997): "The typeface...can convey a mood, signal clues as to content or even suggest a point of view" (p. 43). A move away from these norms can show a move away from tradition and toward informality within the genre (Kress, 1998). This may give insight into how poetry has changed over time across several mediums. Punctuation is used in all poems, though not in every case in "An Etiquette for Eyes" (Marvin, 2014). The beginning of each line is capitalized in "Wonder Song" and "Symphony of a Mexican Garden", but not in "An Etiquette for Eyes" or Atticus's poem. This finding may suggest a change between time periods, as the poems that capitalize each sentence are from the 1912 mediums, while the poems that do not are from the 2014 mediums. This may represent a shift to more informal, less rigid writing. In terms of typography, all poems are written in serif typefaces. Most poems are written in a typeface that closely resembles the Times New Roman typeface. This font first officially appeared in print in 1932 and was fashioned after the following adjectives: “...masculine, English, direct, simple” (Goodman \& Graddol, 1997). Typefaces are created with a certain connotation in mind, and Times New Roman has become a standard in writing, so it may offer legitimation for all the poems, including Instagram. Further evidence of this can be found when assessing the 
screenshots of the other Instagram poems. Cleo Wade, for example, hand-writes a lot of her poems and colours the background. She typically writes in all capital letters, sometimes colouring in letters that are enclosed. This gives her poems a juvenile aesthetic which is more authentic and connected to her as person. R. M. Drake also employs an aesthetic by using an oldfashioned typewriter to type his poems, which he then takes a picture of. This lends an antiqueness, seriousness, and legitimacy to his work, just as using a serif, Times New Roman font might.

\section{Similarities between Harper's and Instagram}

Based on these findings, the most notable observation is that there are many similarities between Harper's and Instagram. These two mediums were the only mediums that contained multiple forms of content on one page or screen, and they were also the mediums with the least total wordcount and highest unique wordcount. Both were not meant to accommodate long form poetry or difficult verse and both have many other forms of content for which readers or users engage with the medium. Though Instagram is considered multimodal because of images, sound, video, and text, Harper's is textually multimodal. Kress (2003) notes that in the past and for print media in general, words cost less than images, making words more prevalent. With new media, which is digital, this difference in cost does not exist, making images more prevalent depending on the medium (Kress, 2003). Also similar is the rate of consumption with both mediums. Periodicals were meant to be consumed and then thrown away. The content needed to be able to be quickly consumed and thus straight-forward (Newcomb, 2004). Part of the change brought by Poetry was to create artwork and promote unorthodox verse that would make each issue a keepsake rather than disposable (Brinkman, 2009). Instagram works in a similar way. Content changes daily, and while poem posts are archived in poets' pages, content is consumed 
in seconds and must quickly be replenished. Scrolling through an Instagram poet's page over a long period of posts will reveal repeated content, also an indicator of how quickly content is consumed and then forgotten.

These similarities are surprising considering that the issue of Harper's and the Instagram posts discussed are mediums that exist (or existed) over one hundred years apart. Their shared attributes indicate a similarity in each society's value of poetry and patterns of consumption of information. In the years leading up to 1912, poetry was understood to be experiencing a crisis which was both "imaginary and real" (Newcomb, 2004, p. 47). Newcomb (2004) states that after 1890 , poets were fighting to stay relevant in a world of increasing informality, especially in terms of writing. The same thing could be said in today's society for poets. Much like critics in their treatment of Instagram poetry, there existed a general yearning to separate from old forms of poetry and a simultaneous refusal to accept new forms (Newcomb, 2004). As noted previously, poetry was not bringing in revenue for large periodicals (Brinkman, 2009). Before Instagram poetry, little attention was paid by the masses, or mainstream media, to poetry (Brinkman, 2009). After Instagram poetry began to flourish, poets turned to print collections to make their work profitable.

Instagram poets are generating more money than poets featured in Harper's. However, their poetry revenue comes from book sales, not posts shared through Instagram. This odd turn from digital, multimodal media back to print media is a notion that Kress (2003) mentioned years prior: “...language-as-writing will increasingly be displaced by image in many domains of public communication, though writing will remain the preferred mode of the political and cultural elite" (p. 1). Print media affords a certain legitimation to creative works that isn't present in digitally birthed works. Selling Kaur's Milk and Honey alongside anthologies like The Best American 
Poetry 2014 adds legitimacy to Kaur's work, while it still enjoys a further reach due to exposure via Instagram.

Print mediums that provide the space needed for long form poetry, like Poetry and The Best American Poetry 2014, allow for diversification in form and in content. As stated previously, restricting a poem based on length will also restrict content. The first issue of Poetry in October 1912 has long been thought of as the medium that kickstarted the era of modernity in terms of poetry (Newcomb, 2004). Beyond allowing poets to write more freely in content, the real revolution was allowing them to write lengthy works, which in turn allowed for a diversification in content. Instagram can be argued as equally revolutionary in shaping contemporary poetry, though critics do not favor the direction that it is taking it in (Naji, 2018). Just as poets had to write easily consumable, straightforward verse for periodicals at the turn of the nineteenth century, Instagram poets have to write verses both short and visually interesting in order to be rapidly consumed as a user scrolls their feed.

\section{Quantitative and Qualitative Methods}

Part $\mathrm{C}$ of the research question asks how quantitative and qualitative methods can answer the research question. Overall, the quantitative and qualitative approaches taken were useful in analysing two elements of poems in mediums: form and content. However, oftentimes it was found that the two are intertwined and some data overlapped with others. The qualitative approach to comparing all mediums proved to be the most inclusive. This may be because of poems being tied to visuality, but also because of a surge in visuals in the twenty-first century. The visual analysis helped to round out information from Instagram poetry that could not be computed using quantitative methods because of a lack of text. Using Voyant or any other linguistic tool is limiting when considering poems that are multimodal. Instagram poems, 
because of their short length, could not be properly analysed using type-token ratios and were difficult to compare with the other textually-dominant poems and mediums.

\section{Conclusion}

By discussing poetry's defining characteristics and grounding the discussion within sociopolitical context, the effects of communication mediums on poetry dissemination were able to be analysed. The way in which mediums dictate the form and content of poetry is most notable through controlling the length of poems admitted. A closer look at twenty poems' content and form resulted in the two being closely related. Form, via length, can limit content in its scope and creative visual capabilities.

Comparing three print mediums and one digital medium through quantitative and qualitative methods proved difficult. This study employed quantitative methods based on linguistics and Zipf's law, which require large amounts of text in order to draw meaningful conclusions. This was difficult due to the multimodal nature of Instagram poems as well as the small scope of this study. The linguistic barriers of analysing the data was one of the major limitations of this study. The qualitative method proved to be more encompassing and inclusive of non-language modes of communication employed through Instagram, but also employed by the other print mediums. All mediums were assessed for their visual layout, even if only words appeared on the pages. As shown through this study, text can be visual, as it is made up of symbols and signifiers (Goodman \& Graddol, 1997).

The other major limitation was the small scope of the study. Five poems per medium were assessed, the total corpus made up of 20 texts and 4,059 words, making up a very small corpus. Because of the limited size, these conclusions cannot be representative of the larger 
whole of the communication mediums discussed. Also limiting to this study was the lack of data collected and researched on Instagram, which is a social media application that does not lend itself to research like the word-based Twitter application, or Facebook, both of which have their own analytics available.

Jacobs (2018) mentioned in the conclusion of his study that it is unknown to him how useful his methods and findings are to contemporary poetry. This study has shown that contemporary poetry which is multimodal in nature and dominantly visual does not lend itself to his methods, nor can standard methods of measuring vocabulary density, word frequency, and word distinctiveness accurately indicate certain patterns due to the extremely short length of most Instagram poetry and the visuals that cannot be quantified.

Future studies should look to finding a way to potentially quantify and compare multimodal, contemporary poems. In general, more methods or updated methods need to be used, as society and poetry have changed enough to require different tools. This study may also indicate a need for a separation between Instagram-based poems and purely linguistic poems. 


\section{Appendix A: Excel Spreadsheets}

\section{Quantitative Analysis: All Mediums}

The following spreadsheets include identical information to the spreadsheets found under "Quantitative Analysis: Harper's and Poetry" and "Quantitative Analysis: The Best American Poetry 2014 and Instagram", with the exception of shared terms. Each section has a different set of shared terms.

Harper's

\begin{tabular}{|c|c|c|c|c|c|c|}
\hline Cateogory & Variables & "In the Town a Wild Bird Singing" & "Land of Rain" & "O Wise and Strong" & "Song" & "Wonder Song" \\
\hline \multirow{3}{*}{ Terms } & Amount of terms & 288 & 93 & 52 & 79 & 206 \\
\hline & Amount of unique terms & 196 & 47 & 39 & 61 & 107 \\
\hline & Ratio & $68 \%$ & $51 \%$ & $75 \%$ & $77 \%$ & $52 \%$ \\
\hline \multirow{7}{*}{ Shared Terms } & Love & 0 & 0 & 0 & 1 & 0 \\
\hline & Things & 0 & 1 & 0 & 0 & 0 \\
\hline & Night & 1 & 0 & 0 & 0 & 1 \\
\hline & Feet & 0 & 0 & 0 & 1 & 0 \\
\hline & Like & 1 & 0 & 0 & 0 & 1 \\
\hline & Heart & 1 & 2 & 0 & 1 & 1 \\
\hline & Hear & 1 & 0 & 0 & 0 & 1 \\
\hline \multirow{3}{*}{ Themes } & Nature & Yes & Yes & No & Yes & Yes \\
\hline & Love & 1 & 1 & Yes & Yes & Yes \\
\hline & Loss & Yes & Yes & Yes & Yes & $\backslash$ \\
\hline
\end{tabular}

\section{Poetry}

\begin{tabular}{|c|c|c|c|c|c|c|}
\hline Cateogory & Variables & "Fish of the Flood" & "I am the Woman" & "Symphony of a Mexican Garden" & "To One Unknown" & "To Whistler, American" \\
\hline \multirow{3}{*}{ Terms } & Amount of terms & 71 & 856 & 1088 & 87 & 160 \\
\hline & Amount of unique terms & 54 & 397 & 565 & 60 & 111 \\
\hline & Ratio & $76 \%$ & $46 \%$ & $52 \%$ & $69 \%$ & $69 \%$ \\
\hline \multirow{7}{*}{ Shared Terms } & Love & 1 & 2 & 0 & 0 & 0 \\
\hline & Things & 0 & 0 & 2 & 1 & 0 \\
\hline & Night & 0 & 1 & 0 & 0 & 1 \\
\hline & Feet & 0 & 0 & 1 & 1 & 0 \\
\hline & Like & 0 & 0 & 6 & 0 & 0 \\
\hline & Heart & 0 & 3 & 4 & 0 & 1 \\
\hline & Hear & 0 & 0 & 1 & 0 & 0 \\
\hline \multirow{3}{*}{ Themes } & Nature & Yes & Yes & Yes & Yes & 1 \\
\hline & Love & 1 & Yes & 1 & Yes & 1 \\
\hline & Loss & 1 & Yes & 1 & Yes & 1 \\
\hline
\end{tabular}

The Best American Poetry 2014

\begin{tabular}{|c|c|c|c|c|c|c|}
\hline Cateogory & Variables & "An Etiquette for Eyes" & "Forties War Widows, Stolen Grain" & "Overturned" & "Passing Through Indian Territory" & "Selection from Tanka Diary" \\
\hline \multirow{3}{*}{ Terms } & Amount of terms & 437 & 155 & 89 & 154 & 136 \\
\hline & Amount of unique terms & 232 & 125 & 61 & 102 & 106 \\
\hline & Ratio & $53 \%$ & $81 \%$ & $69 \%$ & $66 \%$ & $78 \%$ \\
\hline \multirow{7}{*}{ Shared Terms } & Love & 1 & 0 & 0 & 0 & 0 \\
\hline & Things & 0 & 1 & 0 & 1 & 0 \\
\hline & Night & 1 & 0 & 0 & 0 & 0 \\
\hline & Feet & 0 & 0 & 1 & 0 & 0 \\
\hline & Like & 0 & 0 & 3 & 2 & 0 \\
\hline & Heart & 0 & 0 & 1 & 0 & 0 \\
\hline & Hear & 0 & 0 & 1 & 0 & 0 \\
\hline \multirow{3}{*}{ Themes } & Nature & 1 & Yes & 1 & Yes & Yes \\
\hline & Love & Yes & 1 & 1 & 1 & 1 \\
\hline & Loss & Yes & Yes & Yes & Yes & Yes \\
\hline
\end{tabular}




\section{Instagram}

\begin{tabular}{|c|c|c|c|c|c|c|}
\hline Cateogory & Variables & Atticus & Cleo Wade & R. M. Drake & R. H. Sin & Rupi Kaur \\
\hline \multirow{3}{*}{ Terms } & Amount of terms & 11 & 19 & 55 & 13 & 10 \\
\hline & Amount of unique terms & 10 & 18 & 40 & 11 & 10 \\
\hline & Ratio & $91 \%$ & $95 \%$ & $73 \%$ & $85 \%$ & $100 \%$ \\
\hline \multirow{7}{*}{ Shared Terms } & Love & 1 & 1 & 1 & 0 & 0 \\
\hline & Things & 1 & 0 & 0 & 0 & 0 \\
\hline & Night & 0 & 0 & 0 & 0 & 0 \\
\hline & Feet & 0 & 0 & 0 & 0 & 0 \\
\hline & Like & 0 & 0 & 0 & 0 & 0 \\
\hline & Heart & 0 & 0 & 0 & 0 & 0 \\
\hline & Hear & 0 & 0 & 0 & 0 & 0 \\
\hline \multirow{3}{*}{ Themes } & Nature & 1 & 1 & Yes & 1 & 1 \\
\hline & Love & Yes & Yes & Yes & 1 & 1 \\
\hline & Loss & Yes & 1 & Yes & Yes & Yes \\
\hline
\end{tabular}

\section{Quantitative Analysis: Harper's and Poetry}

\section{Harper's}

\begin{tabular}{|c|c|c|c|c|c|c|}
\hline Category & Variables & "In the Town a Wild Bird Singing" & "Land of Rain" & "O Wise and Strong" & "Song" & "Wonder Song" \\
\hline \multirow{3}{*}{ Terms } & Amount of terms & 288 & 93 & 52 & 79 & 206 \\
\hline & Amount of unique terms & 196 & 47 & 39 & 61 & 107 \\
\hline & Ratio & $68 \%$ & $51 \%$ & $75 \%$ & $77 \%$ & $52 \%$ \\
\hline \multirow{7}{*}{ Shared Terms } & Heart & 1 & 2 & 0 & 1 & 1 \\
\hline & Moon & 0 & 1 & 0 & 0 & 1 \\
\hline & Star & 1 & 1 & 0 & 0 & 1 \\
\hline & Little & 1 & 0 & 1 & 2 & 0 \\
\hline & Dream & 1 & 1 & 2 & 0 & 0 \\
\hline & Night & 1 & 0 & 0 & 0 & 1 \\
\hline & Come & 1 & 0 & 0 & 0 & 5 \\
\hline \multirow{3}{*}{ Themes } & Nature & Yes & Yes & No & Yes & Yes \\
\hline & Love & 1 & 1 & Yes & Yes & Yes \\
\hline & Loss & Yes & Yes & Yes & Yes & 1 \\
\hline
\end{tabular}

\section{Poetry}

\begin{tabular}{|c|c|c|c|c|c|c|}
\hline Category & Variables & "Fish of the Flood" & "I am the Woman" & "Symphony of a Mexican Garden" & "To One Unknown" & "To Whistler, American" \\
\hline \multirow{3}{*}{ Terms } & Amount of terms & 71 & 856 & 1088 & 87 & 160 \\
\hline & Amount of unique terms & 54 & 397 & 565 & 60 & 111 \\
\hline & Ratio & $76 \%$ & $46 \%$ & $52 \%$ & $69 \%$ & $69 \%$ \\
\hline \multirow{7}{*}{ Shared Terms } & Heart & 0 & 3 & 4 & 0 & 1 \\
\hline & Moon & 0 & 0 & 8 & 1 & 0 \\
\hline & Star & 0 & 4 & 1 & 0 & 0 \\
\hline & Little & 0 & 2 & 1 & 0 & 1 \\
\hline & Dream & 1 & 0 & 8 & 1 & 0 \\
\hline & Night & 0 & 1 & 0 & 0 & 1 \\
\hline & Come & 0 & 3 & 1 & 0 & 0 \\
\hline \multirow{3}{*}{ Themes } & Nature & Yes & Yes & Yes & Yes & 1 \\
\hline & Love & 1 & Yes & 1 & Yes & 1 \\
\hline & Loss & 1 & Yes & 1 & Yes & 1 \\
\hline
\end{tabular}




\section{Quantitative Analysis: The Best American Poetry 2014 and Instagram}

\section{The Best American Poetry 2014}

\begin{tabular}{|c|c|c|c|c|c|c|}
\hline Category & Variables & "An Etiquette for Eyes" & " "Forties War Widows, Stolen Grain" & "Overturned" & "Passing Through Indian Territory" & "Selection from Tanka Diary" \\
\hline \multirow{3}{*}{ Terms } & Amount of terms & 437 & 155 & 89 & 154 & 136 \\
\hline & Amount of unique terms & 232 & 125 & 61 & 102 & 106 \\
\hline & Ratio & $53 \%$ & $81 \%$ & $69 \%$ & $66 \%$ & $78 \%$ \\
\hline \multirow{6}{*}{ Shared Terms } & Things & 0 & 1 & 0 & 1 & 0 \\
\hline & Got & 1 & 1 & 5 & 0 & 0 \\
\hline & Love & 1 & 0 & 0 & 0 & 0 \\
\hline & Stop & 0 & 0 & 0 & 1 & 0 \\
\hline & I'm/I am & 3 & 0 & 0 & 0 & 1 \\
\hline & Death & 1 & 0 & 0 & 0 & 0 \\
\hline \multirow{3}{*}{ Themes } & Nature & 1 & Yes & 1 & Yes & Yes \\
\hline & Love & Yes & 1 & 1 & 1 & 1 \\
\hline & Loss & Yes & Yes & Yes & Yes & Yes \\
\hline
\end{tabular}

\section{Instagram}

\begin{tabular}{|c|c|c|c|c|c|c|}
\hline Category & Variables & Atticus & Cleo Wade & R. $\mathrm{M}$ & R. H. $\operatorname{Sin}$ & Rupi Kaur \\
\hline \multirow{3}{*}{ Terms } & Amount of terms & 11 & 19 & 55 & 13 & 10 \\
\hline & Amount of unique terms & 10 & 18 & 40 & 11 & 10 \\
\hline & Ratio & $91 \%$ & $95 \%$ & $73 \%$ & $85 \%$ & $100 \%$ \\
\hline \multirow{6}{*}{ Shared Terms } & Things & 1 & 0 & 0 & 0 & 0 \\
\hline & Got & 0 & 0 & 0 & 0 & 0 \\
\hline & Love & 1 & 1 & 1 & 0 & 0 \\
\hline & Stop & 1 & 0 & 0 & 0 & 0 \\
\hline & I'm/I am & 0 & 1 & 0 & 0 & 0 \\
\hline & Death & 0 & 0 & 1 & 0 & 0 \\
\hline \multirow{3}{*}{ Themes } & Nature & 1 & 1 & Yes & 1 & 1 \\
\hline & Love & Yes & Yes & Yes & 1 & 1 \\
\hline & Loss & Yes & 1 & Yes & Yes & Yes \\
\hline
\end{tabular}




\section{Qualitative Analysis: All Mediums}

\begin{tabular}{|c|c|c|c|c|c|}
\hline Category & Question & "Wonder Song" & "Symphony of a Mexican Garden" & "An Etiquette for Eyes" & Atticus \\
\hline \multirow{3}{*}{ Medium } & Type & Print & Print & Print & Digital \\
\hline & Name & Harper's & Poetry & Best American Poetry 2014 & Instagram \\
\hline & Type of access & $\begin{array}{l}\text { Digital: online archive } \\
\text { access }\end{array}$ & Digital: online archive access & Digital: online Ebook & Digital: internet \\
\hline \multirow{4}{*}{ Placement } & $\begin{array}{l}\text { Where is the poem located on the } \\
\text { page/screen? }\end{array}$ & $\begin{array}{l}\text { Middle of the page, } \\
\text { slightly lower than the } \\
\text { centre. }\end{array}$ & Middle centre of each page it is on. & Left-justified on both pages. & Middle-left of the post. \\
\hline & Is it the only work on the page? & No & Yes & Yes & No \\
\hline & What are the borders of the poem? & $\begin{array}{l}\text { The poem is bordered } \\
\text { by an invisible rectangle } \\
\text { rather than the page, as } \\
\text { there is the end of a } \\
\text { prose piece also on the } \\
\text { same page. }\end{array}$ & $\begin{array}{l}\text { The poem's borders extend beyond } \\
\text { the first page and is encompassed } \\
\text { by multiple pages ( } 7 \text { ) }\end{array}$ & $\begin{array}{l}\text { The poem's borders extend } \\
\text { beyond the first page and is } \\
\text { encompassed by multiple } \\
\text { pages (4) }\end{array}$ & $\begin{array}{l}\text { The poem's borders can be } \\
\text { understood as the borders of the } \\
\text { Instagram post, but also can be } \\
\text { understood as non-existent if the } \\
\text { poet's Instagram page is } \\
\text { considered part of the poem. }\end{array}$ \\
\hline & Are the borders clear or undefined? & Clear & Clear & Clear & Unclear \\
\hline \multirow[t]{2}{*}{ Visual aspects } & $\begin{array}{l}\text { Is the poem multimodal? (Contains } \\
\text { modes other than text) If yes, what } \\
\text { mode, and what is being depicted? }\end{array}$ & No & No & No & $\begin{array}{l}\text { Yes, images: four full pictures can } \\
\text { be seen in the screenshot of } \\
\text { Atticus' page. All four are in black } \\
\text { and white. One is of an upside } \\
\text { down shot of a young shirtless } \\
\text { man with a cigarette balanced on } \\
\text { his nose. The next is a young } \\
\text { woman against a blurred } \\
\text { background of trees with long } \\
\text { hair whisping in the wind. } \\
\text { Another is of a couple in bed } \\
\text { holding each other with stacks of } \\
\text { books on a shelf above them, } \\
\text { and another is of the night sky } \\
\text { with the back of a truck and two } \\
\text { peoples' legs visible. }\end{array}$ \\
\hline & Is the text visual? & No & Yes & Yes & No \\
\hline \multirow[b]{2}{*}{ Grammar } & Is punctuation used? & Yes & Yes & Moderately & Yes \\
\hline & $\begin{array}{l}\text { Is the beginning of each line } \\
\text { capitalized? }\end{array}$ & Yes & Yes & No & No \\
\hline Typography & $\begin{array}{l}\text { Is the typeface used serif or sans } \\
\text { serif? }\end{array}$ & Serif & Serif & Serif & Serif \\
\hline
\end{tabular}




\section{Appendix B: Instagram Screenshots}

Each Instagram poet has a screenshot of the poem analysed for this study, represented by "A", and the greater context of the poet's page where it can be found, represented by "B". All screenshots were taken from a cellphone using the Instagram application.

\section{Atticus (@atticuspoetry)}

A

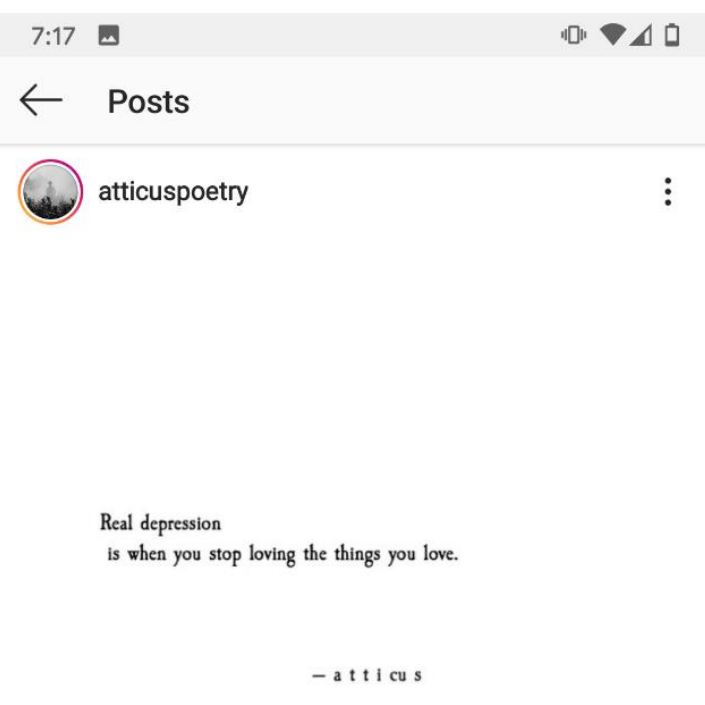

$\bigcirc \bigcirc \nabla$

1,031 likes

View all 33 comments

September 10, 2014

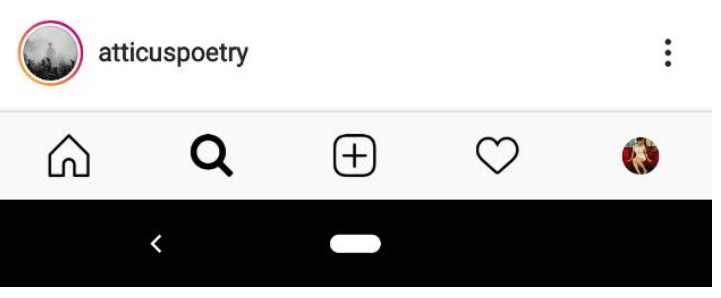

B

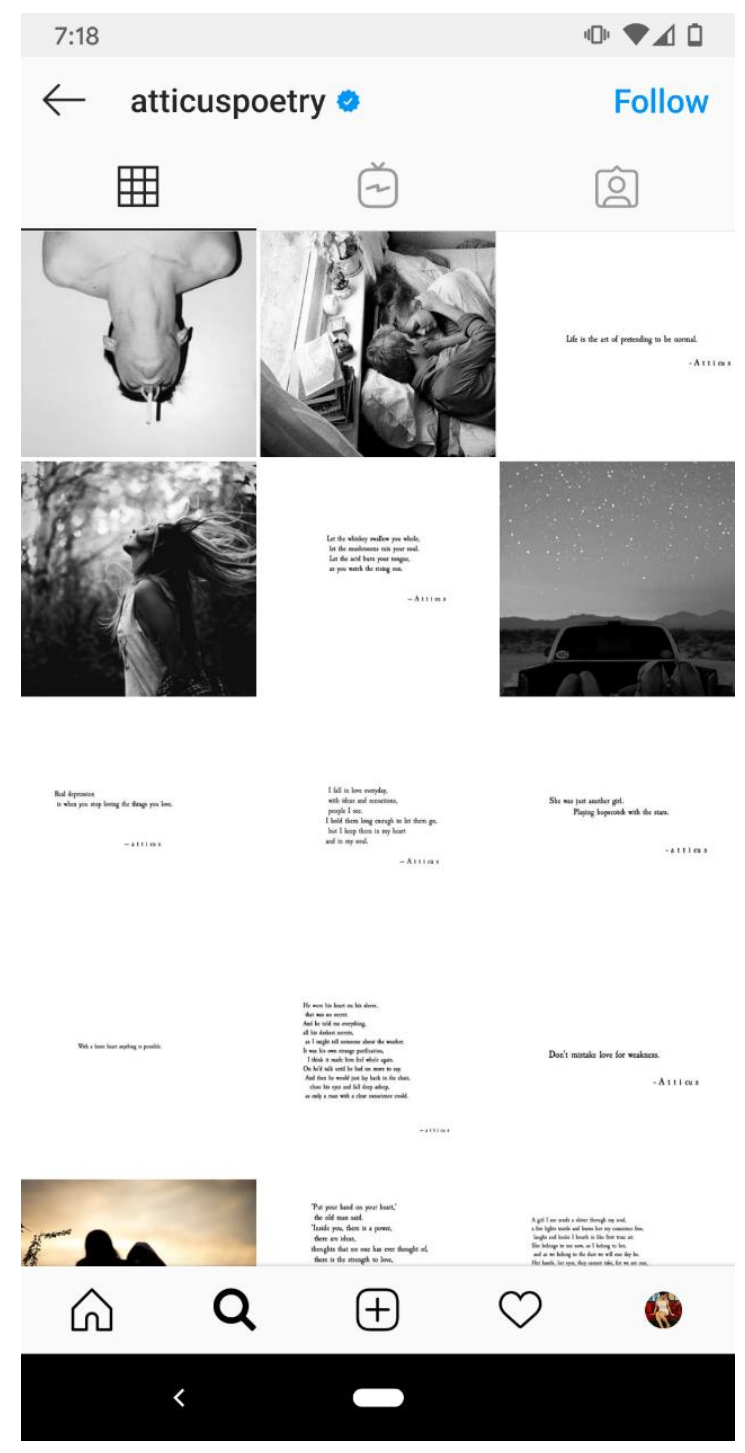




\section{Rupi Kaur (@rupidkaur_)}

A

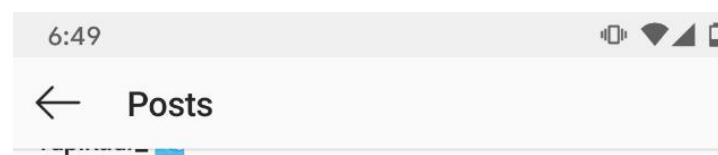

September 15, 2014

(5) rupikaur_

she was music

but he had his ears cut off

- rupi kaur

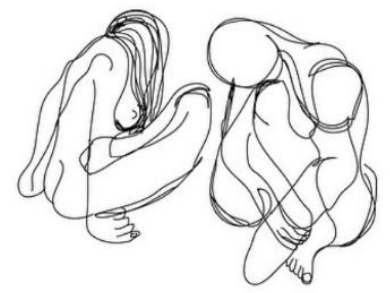

$\bigcirc \bigcirc \nabla$

7,747 likes

rupikaur_ $\%$

View all 343 comments

September 14, 2014
内
Q
$\oplus$
O

ఐ

B

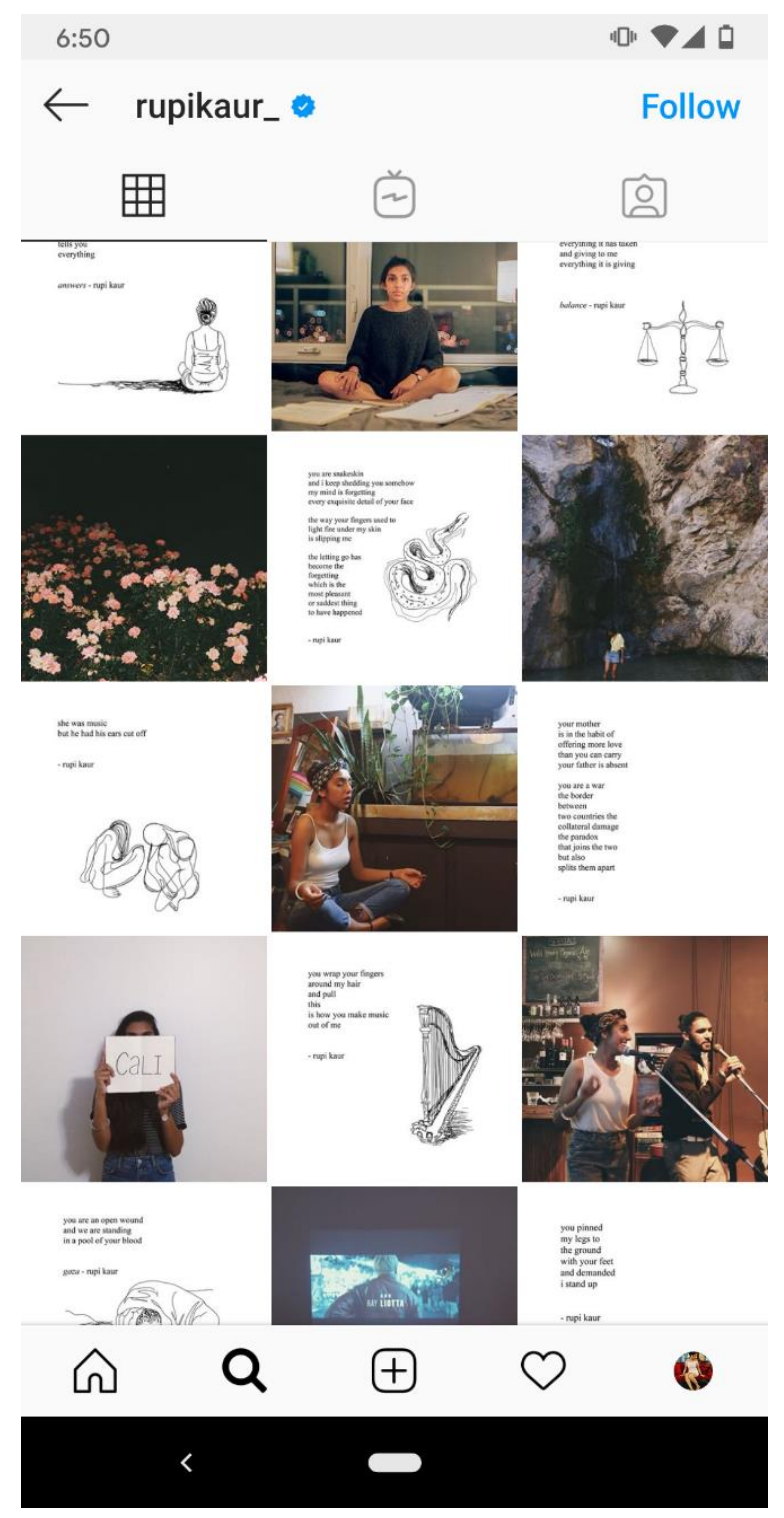




\section{R. M. Drake (@rmdrk)}

A

$6: 55 \square$
$\leftarrow$ Posts

September 10, 2014

rmdrk

she was thunder and her smile would rattle my bones. she couldn't pile herself together but i fell in love with all of her. she was the death of me, the beginning and the end. and $i$ never understood her, for how could someone so beautiful be the cause of so much destruction after all.

$$
r . m . \text { drake }
$$

\section{$\bigcirc \bigcirc \nabla$}

\section{7,063 likes}

rmdrk \#514 by Robert M. Drake \#rmdrake @rmdrk... more

View all 1,605 comments

September 9, 2014

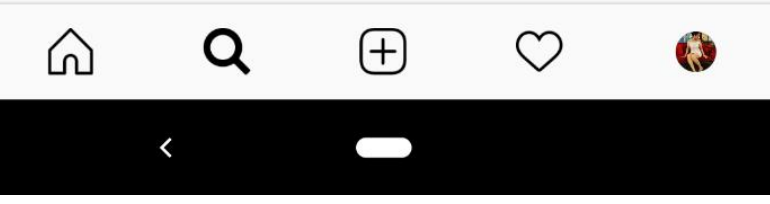

\section{B}

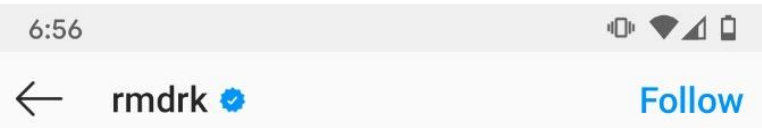

囲

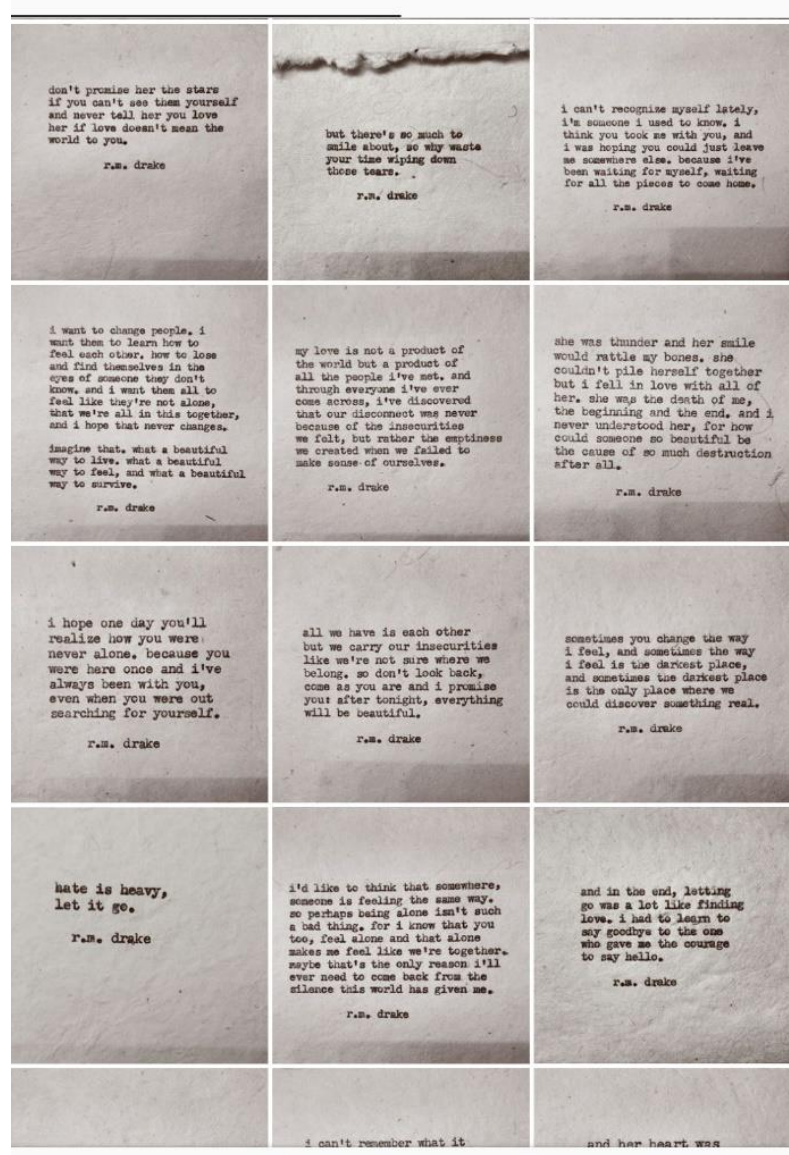

$\widehat{Q} Q$

$\oplus$

O

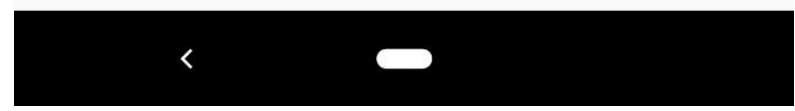




\section{R. H.Sin (@r.h.sin)}

A

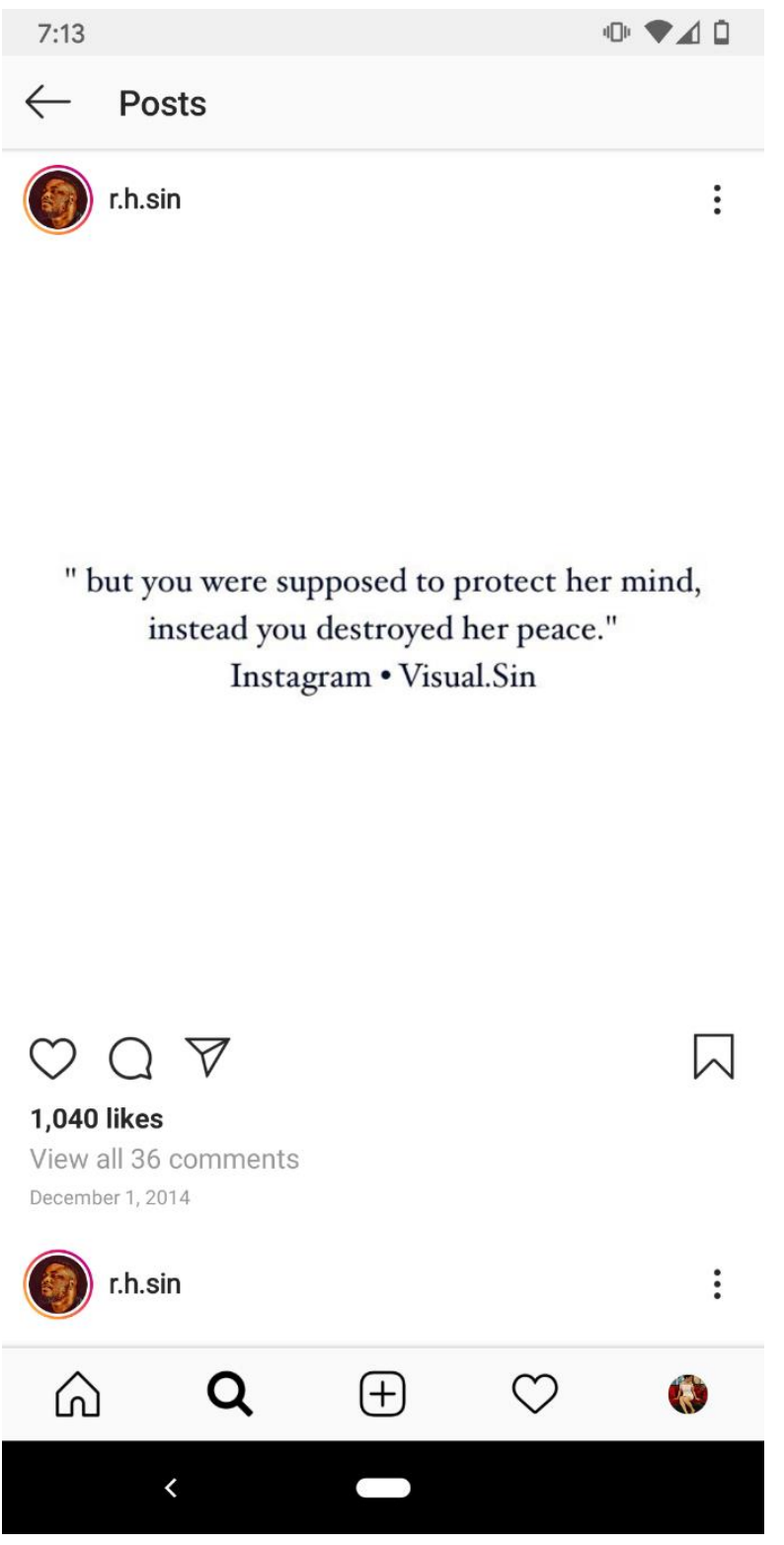

B
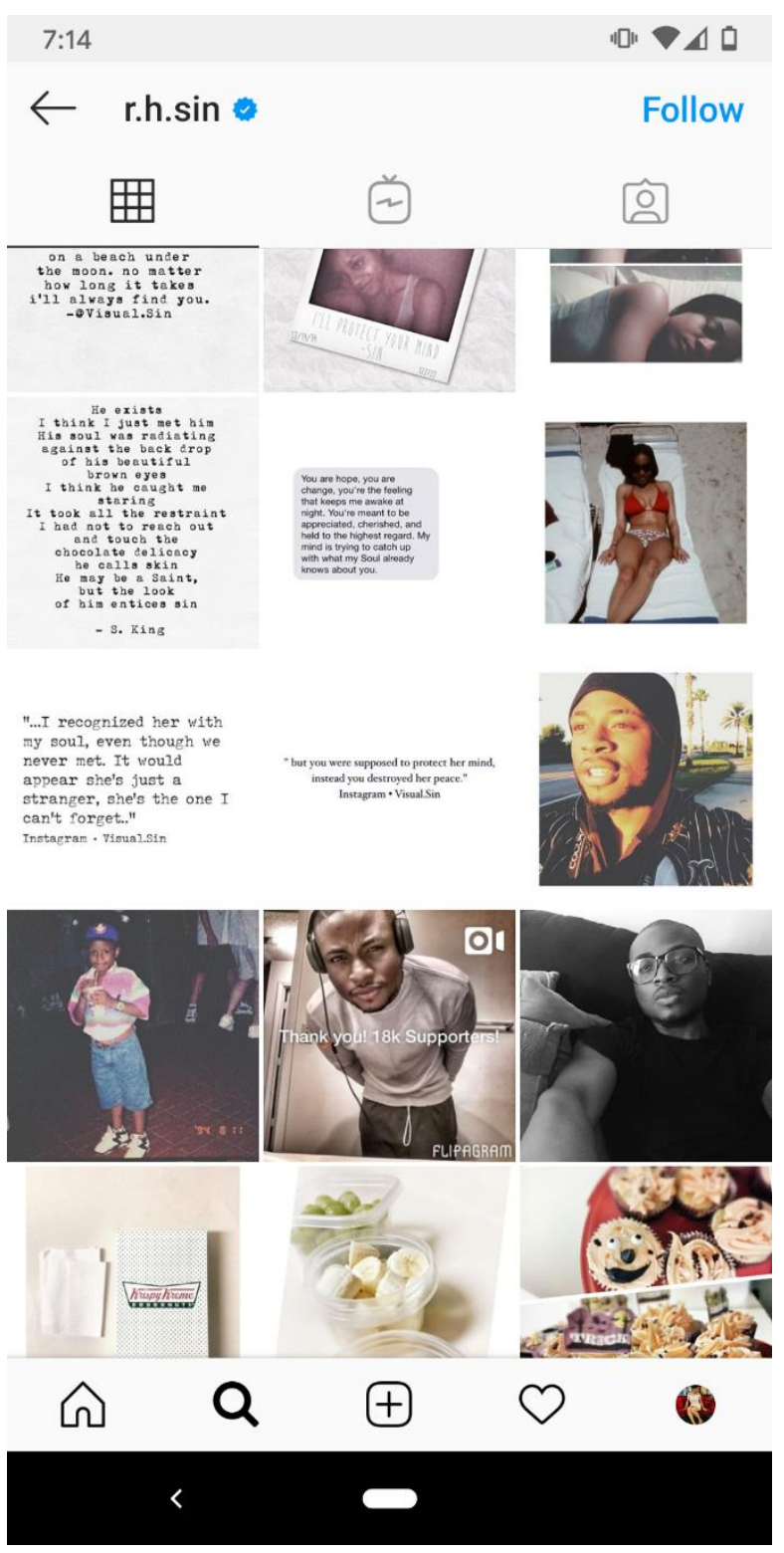


\section{Cleo Wade (@ cleowade)}

A

$7: 23$ Posts
$\leftarrow$ P

November 19, 2014

(10) cleowade

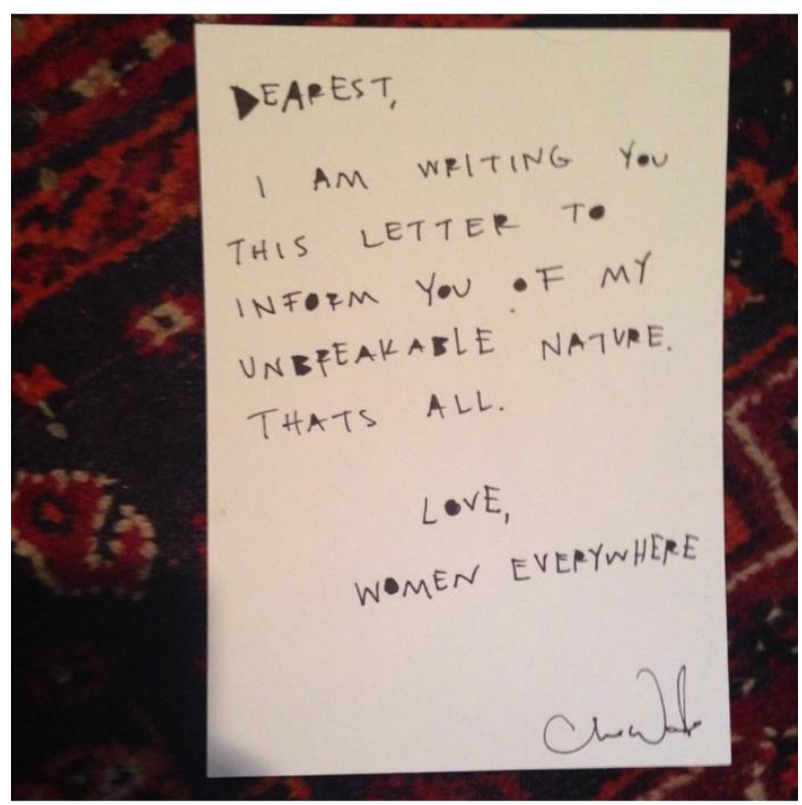

$\odot \bigcirc \nabla$

720 likes

cleowade hi internet.

View all 94 comments

November 18, 2014

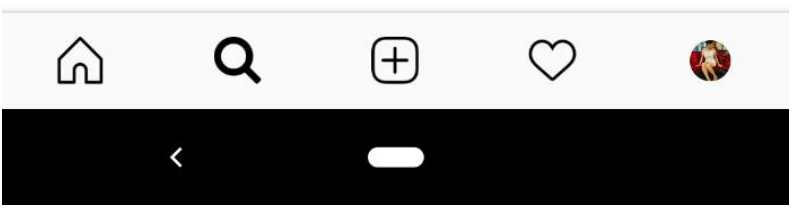

\section{B}
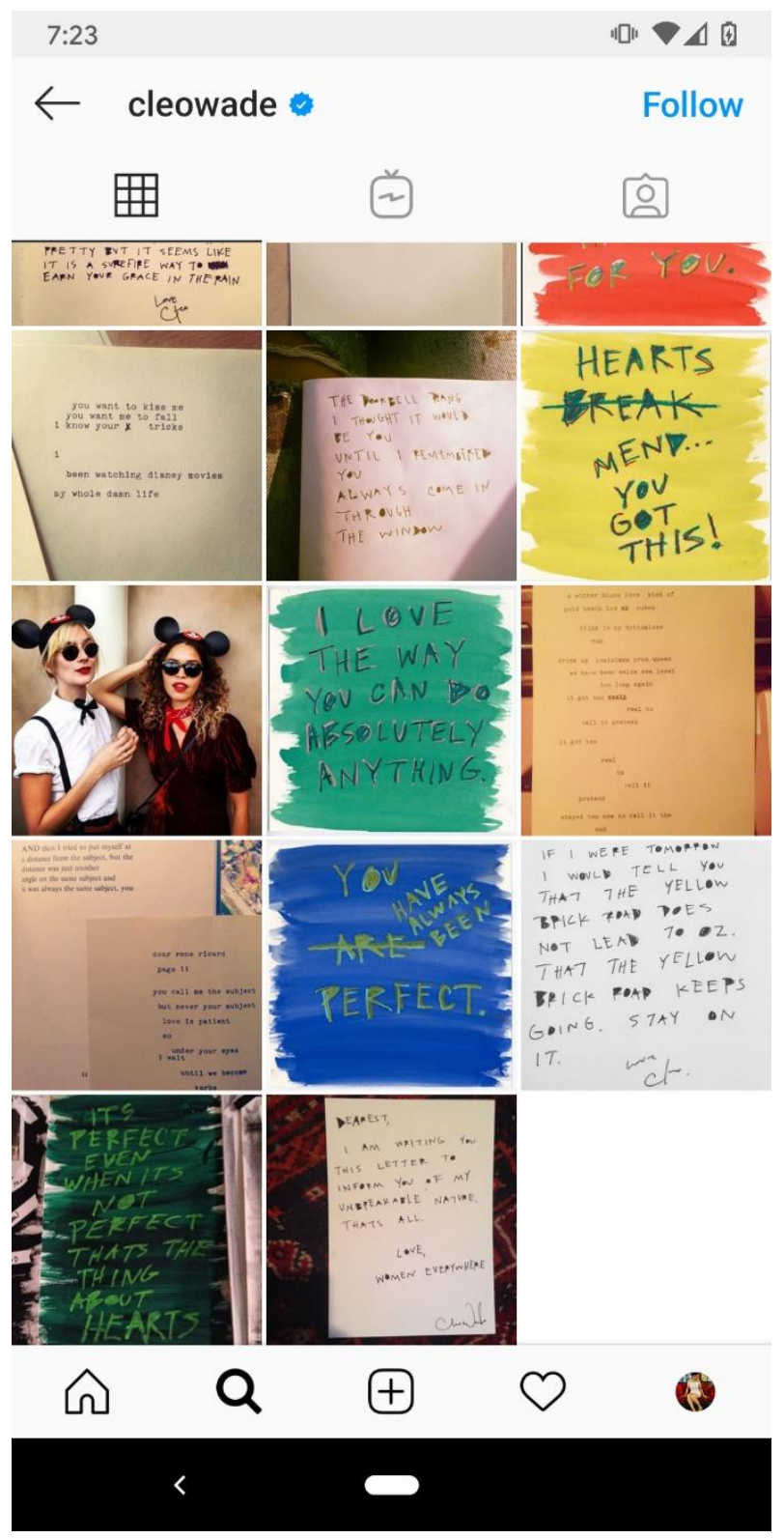


\title{
Appendix C: Qualitative Analysis Poem Screenshots
}

\author{
"Wonder Song", from Harper's
}

738

He nodded, and a moment afterward they "Who is that leaving his room?" he conwere passing along the corridors. Sudden- tinued, as she followed his glance across ly, as they passed a window, Ian stopped. the quadrangle. "Surely it's Fellowes!"

"I thought Mappin went with the others he added. to the Glen," he said.

"He did," was the reply,

"Yes, it looked like Mr. Fellowes," she [TO BE CONTINUED.] said, with a slight frown of wonder.

\section{Wonder Song \\ BY GEORGE PHILLIPS}

ISTEN to my calling

L Where the stars are falling,

Gladness of the Mother-Earth and Beauty of the Sea!

Let us go a-gipsying adown the Lanes of Wonder,

Over and across the world and through the hills and under.

Part the curtain of the skies and come to me, your lover.

Should the lonely way affright, each star shall be your brother;

And the Moon, your sister, shall lead you by the hand,

Till you come, O Starry-Fyed, to where I longing stand.

Listen to my ealling

Where the stars are falling.

Bending down to marvel at the softness of your eyes.

Heed them not, $\mathrm{O}$ Wonder.

Thrust their rays asunder,

Lest they draw you up to be the glory of their skies.

Come to me, Beloved, across the world and under-

Hear you not my beating heart like breaking foam in thunder?

Come and quench the burning

By your great returning.

Till I cool my fever in your dew-drenched eyes.

Listen to my ealling

Where the stars are falling.

Ending of the old world, beginning of the new.

Bid the night-winds bring you,

And the thrushes sing you,

Till you come to where I stand and watch and wait for you. 
Sample of "Symphony of a Mexican Garden" from Poetry

A

\section{SYMPHONY OF A MEXICAN GARDEN}

1. The garden Poco sostenuto in A major The laving tide of inarticulate air.

Vivace in A major

The iris people dance.

2. THE POOL Allegretto in A minor Cool-hearted dim familiar of the dove.

3. THE BIRds Presto in F major

I keep a frequent tryat.

Presto meno assai

The blossom-powdered orange-tree.

4. TO THE MOON Allegro con brio in A major Moon that shone on Babylon.

TO MOZART

What junipers are these, inlaid

With flame of the pomegranate tree?

The god of gardens must have made

This still unrumored place for thee

To rest from immortality,

And dream within the splendid shade

Some more elusive symphony

Than orchestra has eoer played.

[11] 
POETRY: A Magazine of Verse

I In A major

Poco sostenuto

The laving tide of inarticulate air

Breaks here in flowers as the sea in foam,

But with no satin lisp of failing wave:

The odor-laden winds are very still.

An unimagined music here exhales

In upcurled petal, dreamy bud half-furled,

And variations of thin vivid leaf:

Symphonic beauty that some god forgot.

If form could waken into lyric sound,

This flock of irises like poising birds

Would feel song at their slender feathered throats,

And pour into a grey-winged aria

Their wrinkled silver fingermarked with pearl;

That flight of ivory roses high along

The airy azure of the larkspur spires

Would be a fugue to puzzle nightingales

With too-evasive rapture, phrase on phrase.

Where the hibiscus flares would cymbals clash,

And the black cypress like a deep bassoon

Would hum a clouded amber melody.

But all across the trudging ragged chords

That are the tangled grasses in the heat,

The mariposa lilies fluttering

Like trills upon some archangelic flute,

[12] 
"An Etiquette for Eyes" from The Best American Poetry

A

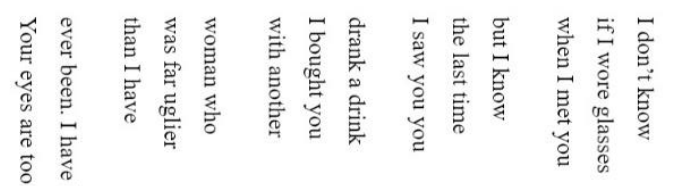

호일

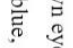

蛋

产

莹

言

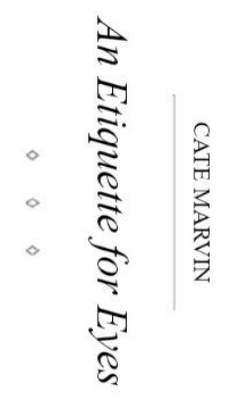

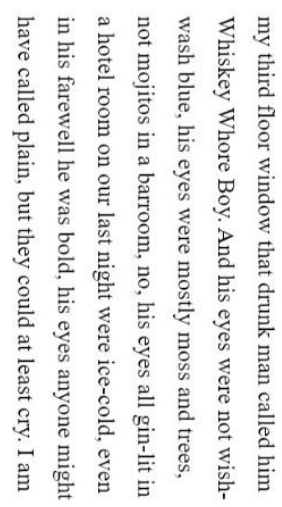

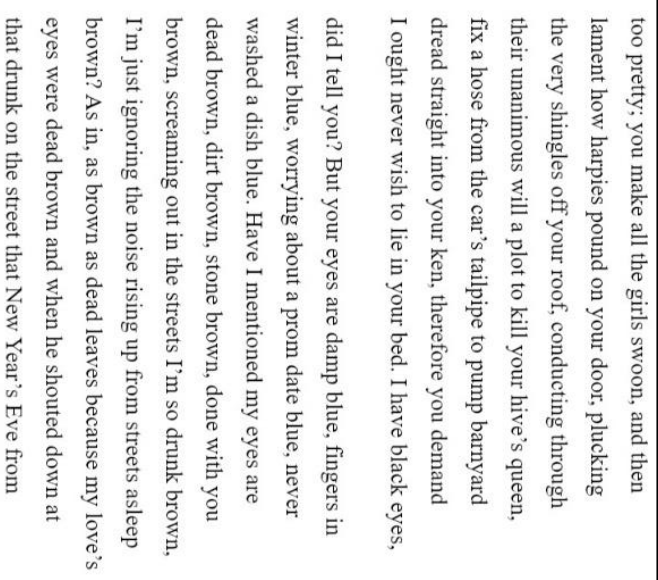




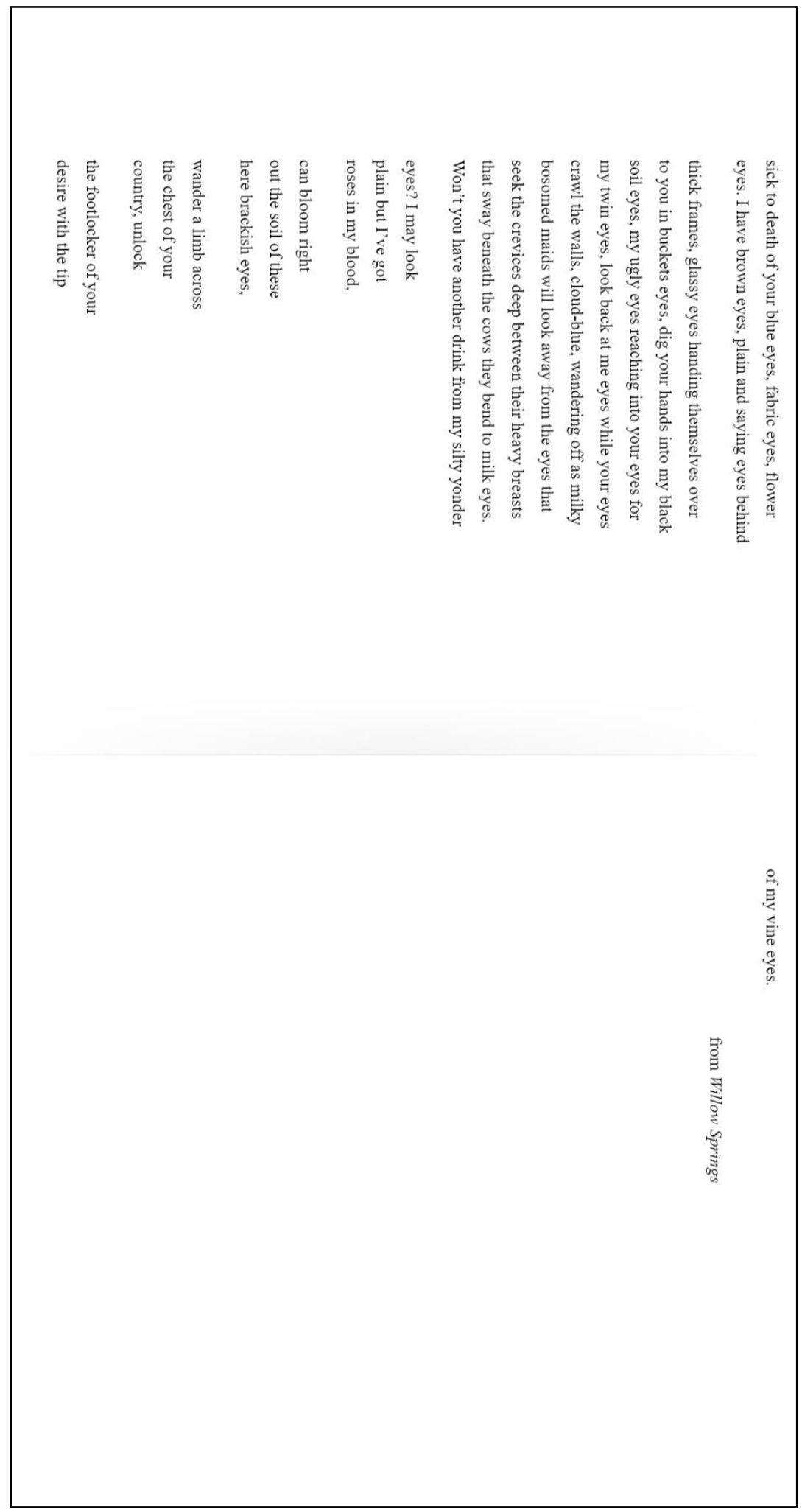




\section{References}

Atticus [@atticuspoetry]. (2014, September 10). Real depression is when you stop loving the things you love. [Photograph]. Instagram. https://www.instagram.com/p/syMoNzJP_7/

Benjamin, Walter. (1982). The Work of Art in the Age of Mechanical Reproduction in Modern Art and Modernism: A Critical Anthology by Francisca Francis (Zohn, Harry, Trans.) (p. 217-220). Routledge. http://eq6sp2kj9f.search.serialssolutions.com/

Berens, Kathy Inman (2019). “E-Lit’s \#1 Hit: Is Instagram Poetry E-Literature?” in Electronic Book Review. https://doi.org/10.7273/9sz6-nj80

Brinkman, B. (2009). Making Modern "Poetry": Format, Genre and the Invention of Imagism(e). Journal of Modern Literature, 32(2), 20-40. www.jstor.org/stable/25511802

Bunner, Anne. (1912, October 1). O wise and strong. A poem. Harper's Monthly Magazine; (Cover Title: Harper's Magazine), 125(749), 674. http://ezproxy.lib.ryerson.ca/login?url=https://search-proquest com.ezproxy.lib.ryerson.ca/docview/1301510411 accountid=13631

Churchill, S. W. (1998). Making space for "others": A history of a modernist little magazine. Journal of Modern Literature, 22(1), 47-67.

Coates, Florence Earle. (1912, October 1). In the town a wild bird singing. A poem. Harper's Monthly Magazine; (Cover Title: Harper's Magazine), 125(749), 745. http://ezproxy.lib.ryerson.ca/login?url=https://search-proquest com.ezproxy.lib.ryerson.ca/docview/1301510610 accountid=13631 
Conkling, Grace Hazard. (1912, October). Symphony of a Mexican Garden. Poetry: A Magazine of Verse, 1(1), 11-18. https://www.poetryfoundation.org/poetrymagazine/browse?volume=1\&issue=1\&page= 4

Drake, R. M. [@ rmdrk]. (2014, September 9). she was thunder and her smile would rattle my bones. [Photograph]. Instagram. https://www.instagram.com/p/svxHBSjyMg/?fbclid=IwAR2tdBtQ9vT5837wMfvbTtUs 96TUwdQbItw4Q8w15OPECT162LB2X6AwR4

Dudley, Helen, (1912, October). To One Unknown. Poetry: A Magazine of Verse, 1(1), 10. https://www.poetryfoundation.org/poetrymagazine/browse $?$ volume=1\&issue $=1 \&$ page $=$ 6

Eady, Cornelius. (2014). Overturned. In Hayes, Terrance., Lehman, David. (Eds.), The Best American Poetry 2014. (pp. 82-83). Scribner Poetry. https://play.google.com/books/reader?id=TFNXAgAAQBAJ\&pg=GBS.PR4

Gallienne, Richard Le. (1912, October 1). Land of rain. A poem. Harper's Monthly Magazine; (Cover Title: Harper's Magazine), 125(749), 662. http://ezproxy.lib.ryerson.ca/login?url=https://search-proquest com.ezproxy.lib.ryerson.ca/docview/1301510371 accountid=13631

Glasgow, Ellen. (1912, October 1). Song. A poem. Harper's Monthly Magazine; (Cover Title: Harper's Magazine), 125(749), 694. http://ezproxy.lib.ryerson.ca/login?url=https://search proquest-com.ezproxy.lib.ryerson.ca/docview/1301510493?accountid=13631 
Goodman, S., \& Graddol, D. (1997). Redesigning english: New texts, new identities. Retrieved from https://ebookcentral-proquest-com.ezproxy.lib.ryerson.ca

Jacobs, M. Arthur. (2018). The Gutenberg English Poetry Corpus: Exemplary Quantitative Narrative Analyses. Frontiers in Digital Humanities, 5, 1-14. https://doi.org/10.3389/fdigh.2018.00005.

Kaur, Rupi [@rupikaur_]. (2014, September 9). she was music but he had his ears cut off. [Photograph]. Instagram. https://www.instagram.com/p/s8st70HAzP/

Kress, G. (2003). Literacy in the New Media Age. Routledge. https://ebookcentral-proquest com.ezproxy.lib.ryerson.ca

Kress, G. (1998). Visual and verbal modes of representation in electronically mediated communication: The potentials of new forms of text. In I. Snyder (Ed.), Page to screen: Taking literacy into the electronic era (p. 53- 79). Routledge.

Lorimer, Emelia Stuart. (1912, October). Fish of the Flood. Poetry: A Magazine of Verse, 1(1), 9. https://www.poetryfoundation.org/poetrymagazine/browse? volume $=1 \&$ issue $=1 \&$ page $=15$

Marvin, Cate. (2014). An Etiquette for Eyes. In Hayes, Terrance., Lehman, David. (Eds.), The Best American Poetry 2014. (pp. 132-134). Scribner Poetry. https://play.google.com/books/reader?id=TFNXAgAAQBAJ\&pg=GBS.PR4

Masters, Edgar Lee. (1915). "What is Poetry?" Poetry: A Magazine of Verse, 6, 306-08. https://www.poetryfoundation.org/poetrymagazine/browse?contentId=58981 
McVee, M., Bailey, N., \& Shanahan, L. (2008). Using Digital Media to Interpret Poetry: Spiderman Meets Walt Whitman. Research in the Teaching of English, 43(2), 112-143. www.jstor.org/stable/40171762

Moody, William Vaughn. (1912, October). I am the Woman. Poetry: A Magazine of Verse, 1(1), 3-6. https://www.poetryfoundation.org/poetrymagazine/browse?contentId=12586

Mullen, Harryette. (2014). Selection from Tanka Diary. In Hayes, Terrance., Lehman, David. (Eds.), The Best American Poetry 2014. (pp. 143-144). Scribner Poetry. https://play.google.com/books/reader?id=TFNXAgAAQBAJ\&pg=GBS.PR4

Naji, Jeneen (2018). The Posthuman Poetics of Instagram Poetry. In: EVA Copenhagen 2018 Politics of the Machines - Art and After. (p. 1-7.) https://doi.org/10.14236/ewic/EVAC18.1

Newcomb, John Timberman. (2004) Would Poetry Disappear? American Verse and the Crisis of Modernity. Ohio State University Press.

Osborne, Peter., Charles, Matthew. (2015 July 22). Stanford Encyclopedia of Philosophy. https://plato.stanford.edu/entries/benjamin/

Phillips, George. (1912, October 1). Wonder song. A poem. Harper's Monthly Magazine; (Cover Title: Harper's Magazine), 125(749), 738. http://ezproxy.lib.ryerson.ca/login?url=https://search-proquest com.ezproxy.lib.ryerson.ca/docview/1301510575?accountid=13631 
Pâquet, Lili. (2019). Selfie-Help: The Multimodal Appeal of Instagram Poetry. The Journal of Popular Culture, 52(2), 296-314. https://doiorg.ezproxy.lib.ryerson.ca/10.1111/jpcu.12780.

Plato. (1968). The Republic. (A. Bloom, Trans.) New York: Basic Books. (c. 375 BC). https://courses.ryerson.ca/d21/le/content/348213/viewContent/2758885/View

Pound, Ezra. (1912, October). To Whistler, American. Poetry: A Magazine of Verse, 1(1), 7. https://www.poetryfoundation.org/poetrymagazine/ browse volume $=1 \&$ issue $=1 \&$ page $=13$

Serafinelli, E. (2018). Digital life on Instagram: New social communication of photography. Emerald Publishing Limited. https://ebookcentral-proquest-com.ezproxy.lib.ryerson.ca

Sin, R. H. [@r.h.sin]. (2014, December 1). but you were supposed to protect her mind, instead you destroyed her peace. [Photograph]. Instagram. https://www.instagram.com/p/wFlawQNoMC/?fbclid=IwAR2C3NdvKPdVyA6i_d cS0DAIeMx7ZSIXAMv5jM58BUioAbW1qdrcI3XKxE

Sinclair, Stéfan and Geoffrey Rockwell, 2016. Voyant Tools. http://voyant-tools.org/.

Slinn, E. (1999). Poetry and Culture: Performativity and Critique. New Literary History, 30(1), 57-74. www.jstor.org/stable/20057522

Springer, Jane. (2014). Forties War Widows, Stolen Grain. In Hayes, Terrance., Lehman, David. (Eds.), The Best American Poetry 2014. (pp. 170-171). Scribner Poetry. https://play.google.com/books/reader?id=TFNXAgAAQBAJ\&pg=GBS.PR4 
Szabó, K. (2016). Digital and Visual Literacy: The Role of Visuality in Contemporary Online Reading. In Benedek A. \& Veszelszki Á (Eds.), In the Beginning was the Image: The Omnipresence of Pictures: Time, Truth, Tradition (p. 103-112). Frankfurt am Main:

Peter Lang AG. www.jstor.org/stable/j.ctv2t4cns.12

Wade, Cleo [@ cleowade]. (2014, November 18). Dearest, I am writing this letter to inform you of my unbreakable nature. That's all. Love, Women Everywhere. [Photograph]. Instagram. https://www.instagram.com/p/vkTXPANmxu/

Wang, Dorothy J. Thinking Its Presence: Form, Race, and Subjectivity in Contemporary Asian American Poetry, Stanford University Press, 2013. ProQuest Ebook Central, https://ebookcentral-proquest com.ezproxy.lib.ryerson.ca/lib/ryerson/detail.action?docID=1543730.

Weaver, Afaa Michael. (2014). Passing Through Indian Territory. In Hayes, Terrance., Lehman, David. (Eds.), The Best American Poetry 2014. (pp. 173-174). Scribner Poetry. https://play.google.com/books/reader?id=TFNXAgAAQBAJ\&pg=GBS.PR4 